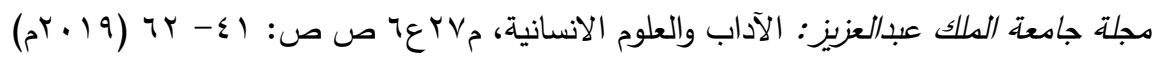

\title{
تتظيمُ المحاكم واختصاصاتُها في جمهورية الصين الشعبية دراسة مقارنة بمحاكم المملكة العربية السعودية
}

\author{
محمد عايض محمد عسيري

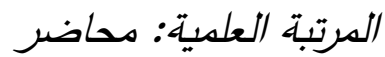 \\ التخصص: القانون الدولي التي \\ الآداب والمعلوم الإنسانية - جامعة الملك عبد العندي العزئ
}

مستخلص. في ظل التطور والنمو الاقتصادي الذي تشهده جمهورية الصين الشعبية، والذي تحتل به المرتبة الثانية عالمياً في الاقتصاد، ويفد إليها آلاف التجار والمستثمرين من أنحاء العالم للاستيراد والتصدير والاستثمار ، وتبرم

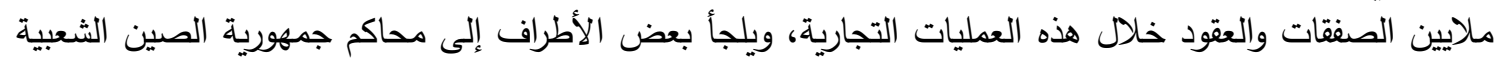

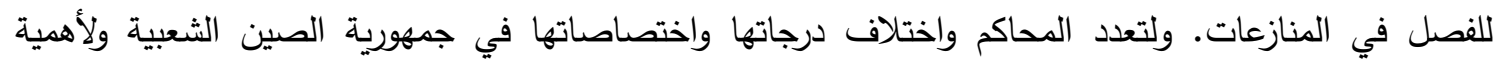

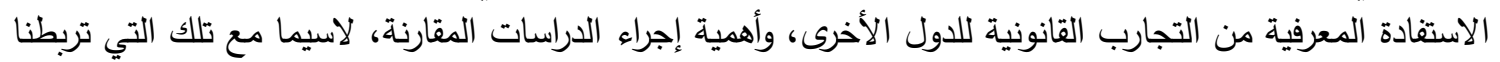

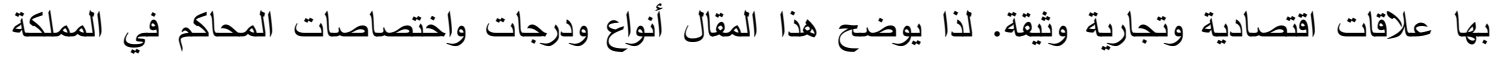

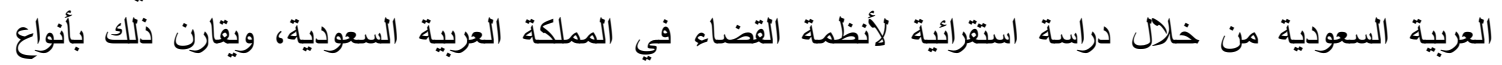

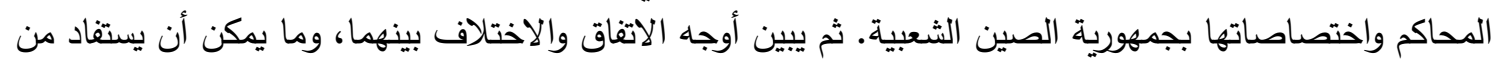
ذلك في تطوير القضاء.

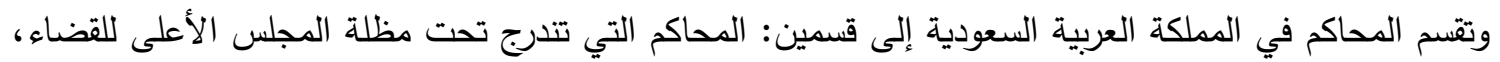

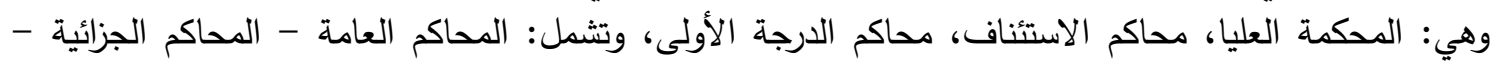

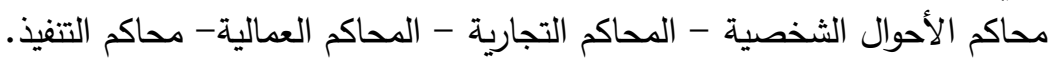
القسم الثاني: المحاكم الإدارية المندرجة تحت مظلة ديوان المظالم، وهي: المحكمة الإدارية العليا، محاكم الاستئناف الإدارية، المحاكم الإدارية. وتقسم المحاكم الثعبية بجمهورية الصين الثعبية إلى الثحادية المحكمة الشعبية العليا، والمحاكم الشعبية المحلية، والمحاكم الشعبية الخاصة. وتعتبر المحكمة الشعبية العليا هي أعلى جهاز قضائي في الدولة، وتتولى البت في القضائيا

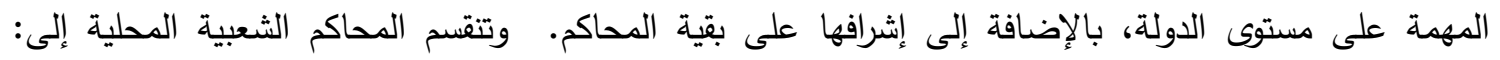
المحكمة الشعبية الابتدائية، والمحكمة الشعبية المتوسطة، والمحكمة الشعبية العالية، وبالنسبة للمحاكم الشعبية الخاصة فتشمل المحاكم العسكرية والمحاكم البحرية ومحاكم الملكية الفكرية والمحاكم المالية وغيرها. الكلمات المفتاحية: المحاكم - الاختصاص القضائي- الصين - قانون

والمستثمرين للاستيراد والتصدير والاستثمار، وتُبرَم

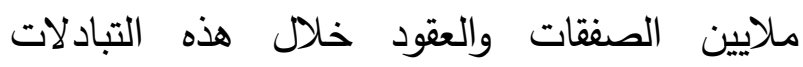

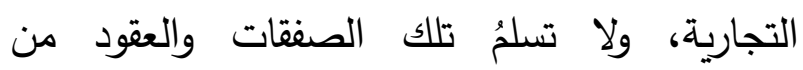
منازعاتٍ بين الأطراف، إما في العقد ذاته وإما في

\section{مقدمة - مقة}

تحتلُ جمهورية الصين الثعبية المرتبة الثانية عالمياً

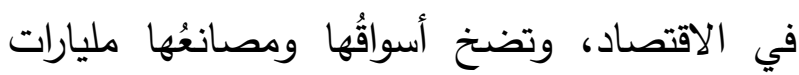

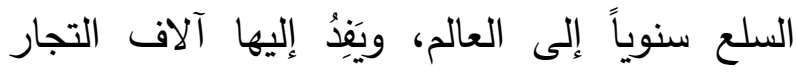




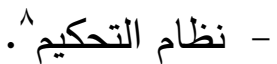

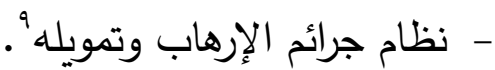
ثانيا: قوانين جمهورية الصين الثعبية: - القانون الدستوري لجمهورية الصين الشعبية' '.

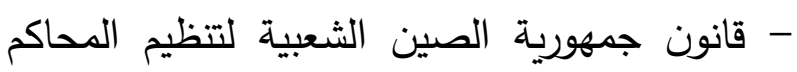

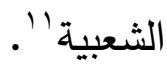

-

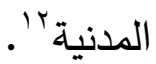

- قانون جمهورية الصين الشعبية للدعاوى

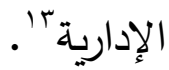

- قانون جمهورية الصين الشعبية للدعاوى

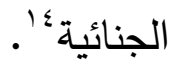
- قانون جمهورية الصين الشعبية للتحكيمْْئ.

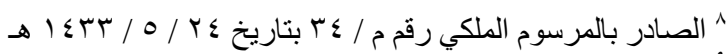

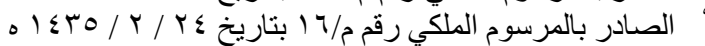

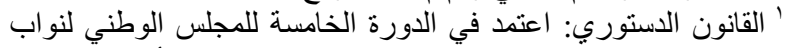

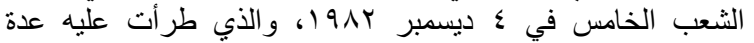

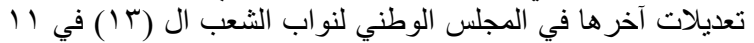

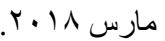

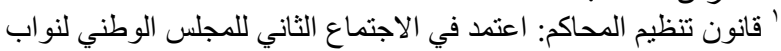

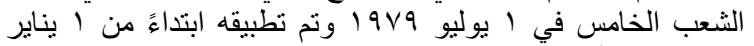

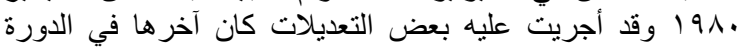

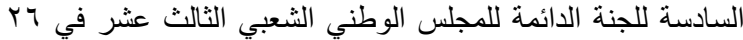

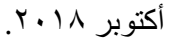
"' قانون الدعاوى المدنية: اعتدد في الدورة الرابعة للمجلس الوطني

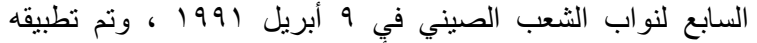

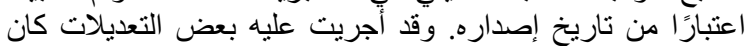

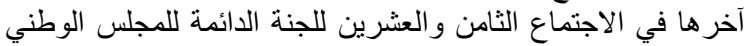

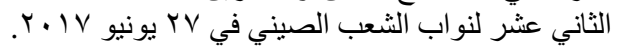

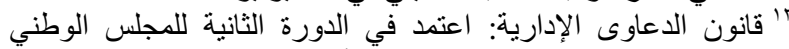

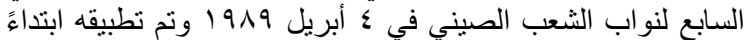

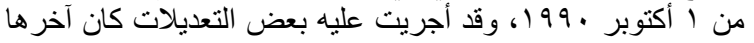

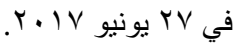

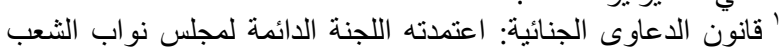

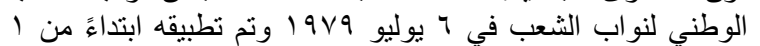

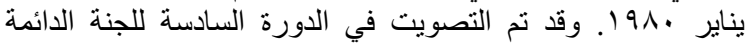

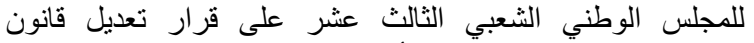

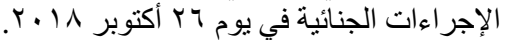

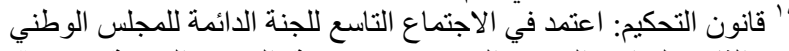

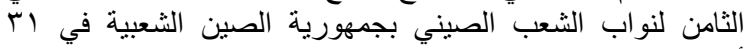

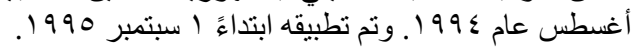

السلعة أو ثمنها وغير ذلك. ولتسوية تلك المنازعات

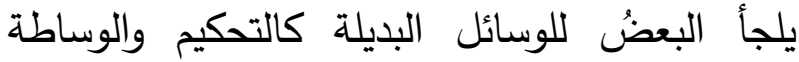
والصلح، بينما يلجأ آخرون إلى القضاء للفصل في للفي تلك المنازعات. ولتعدد المحاكم واختلاف درجاتها واختصاصاتها في

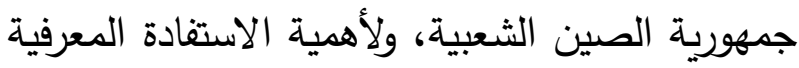

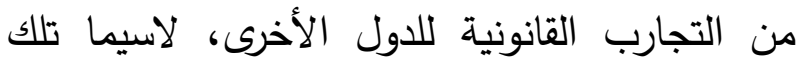

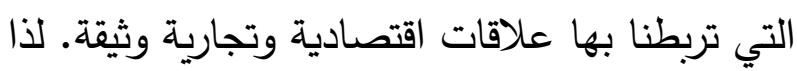
أود في هذا المقال أن أشير إلى أنواع ودرجات تلك تلك

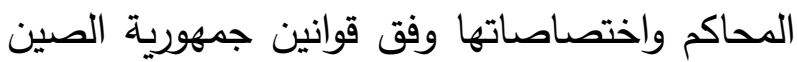
الثعبية، مقارناً ذلك بأنواع ودرجات واختصاتصات واتصات واتهات

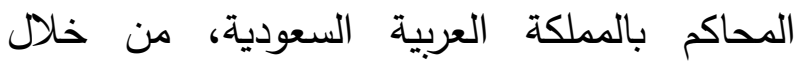
استعراض الأنظمة والقوانين المنظمة لها، ثم خاتمة تشتمل على دراسة مقارنة بينهما.

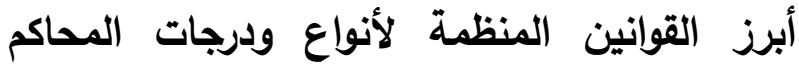
واختصاصاتها أولا: أنظمة المملكة العربية السعودية:

$$
\begin{aligned}
& \text { - نظام القضاء '. } \\
& \text { - نظام المرافعات الشرعية'. }
\end{aligned}
$$

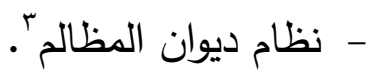

- نظام المرافعات أمام ديوان المظالم؛ - نظأ -

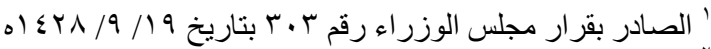

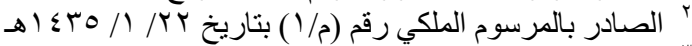

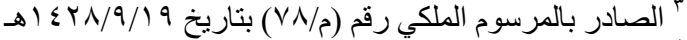

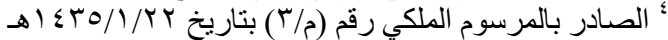

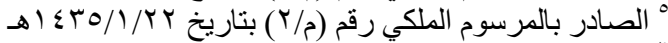

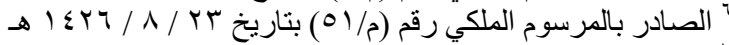

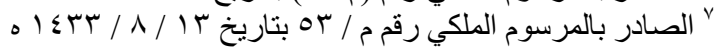




$$
\begin{aligned}
& \text { r- محاكم الاستئناف الإدارية. }
\end{aligned}
$$

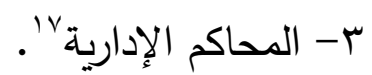

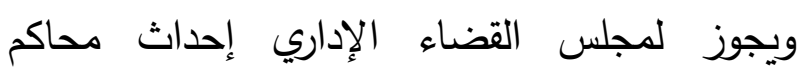

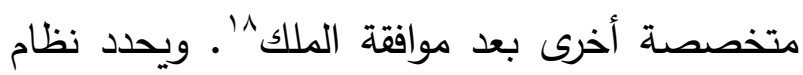
ديوان المظالم، ونظام المرافعات أمام ديوان المظالم اختصاص كل محكمة كما سيأتي تفصيله بإذن الله. المجلس الأعلى للقضاء المجلس الأعلى للقضاء هو الجهة الإدارية المشرفة للقطاء

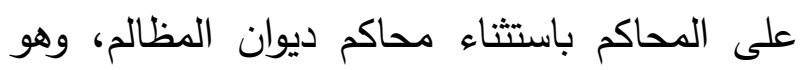
وإن لم يكن محكمة تمارس القضاء إلا أنني أذكره هنا إثارة إلى الجهة التي تتولى الإشراف الإداري على المحاكم في المملكة العربية السعودية. يشكل المجلس الأعلى للقضاء من رئيس يسمى بأمر المعل ملكي، وعشرة أعضاء على النحو الآتي: أ - رئيس المحكمة العليا.

ب - أربعة قضاة متفرغين بدرجة رئيس محكمة استئناف، يسمون بأمر ملكي.

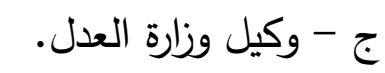
د - رئيس النيابة العامة. هـ - ثلاثة أعضاء يتوافر فيهم ما يشترط في قاضية لئي استئناف، يسمون بأمر ملكي. وتكون مدة اعتراء رئيس المجلس، والأعضاء المنصوص علينه في الفترتين

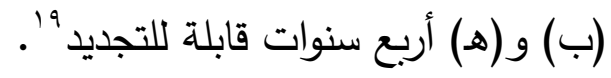

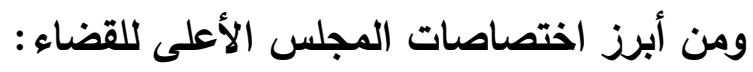
أ - النظر في شؤون القضاة الوظيفية، من تعيين وترقية وتأديب وندب وإعارة وتدريب ونقل وإجازة

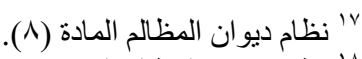

^^ ^نظام ديو ان المظالم المادة (^) (^). 19 1' نظام القضاء المادة (0).
}

بالإضافة إلى العديد من قرارات المحكمة الثعبية العليا المتعلقة بتنظيم المحاكم واختصاصاتها حسب السلطة الممنوحة لها وفق القانون.

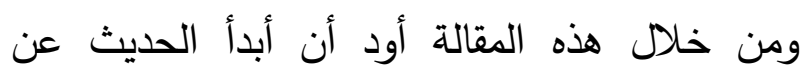

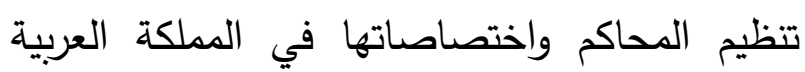
السعودية (جمعاً وتحقيقاً) ثم تنظيم المحاكم واختصاصاتها في جمهورية الصين الشعبية (ترجمةً من اللغة الصينية وجمعاً وتحقيقاً) ثم التعقيب بنتائج تلك المقارنة (دراسة وتحليلاً). محاكم المملكة العربية السعودية تنقسم المحاكم في المملكة العربية إلى قسمين:

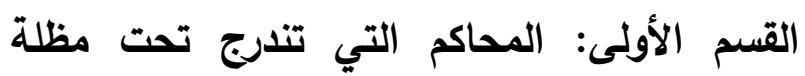
المجلس الأعلى للقضاء، وهي المحاكم التالية: 1 - المحكمة العليا. r - ب - محاكم الاستئناف. r - محاكم الدرجة الأولى، وهي:

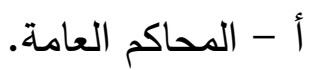
ب- المحاكم الجزائية. ج- محاكم الأحوال الثخصية. د- د - المحاكم التجارية. هـ - المحاكم العمالية. و - محاكم التتفيذ ويحدد كل من نظام المرافعات الشرعية، ونظام

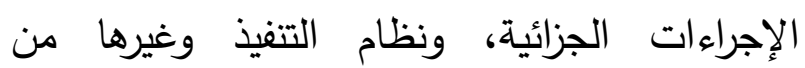

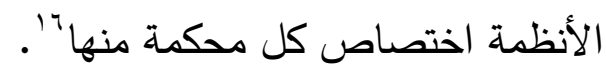

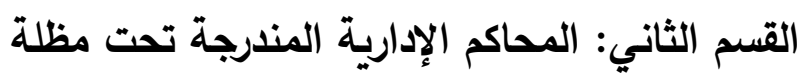
ديوان المظالم، وهي المحاكم التالية: 1- المحكمة الإدارية العليا. 
م- إحداث محاكم متخصصة غير المنصوص عليها في المادة (التاسعة) من نظام القضاء وذلك بعد

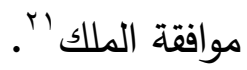

المحكمة العليا

تقع المحكمة العليا في مدينة الرياض، ويعين رئيس

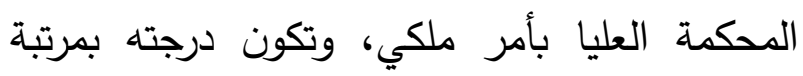
وزير ولا تتهى خدمته إلا بأمر ملكي.

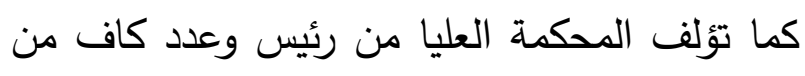
القضاة بدرجة رئيس محكمة استئناف، وتكون تسمية وعنية

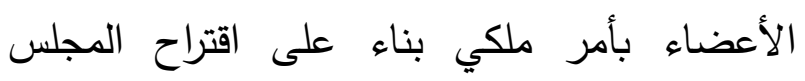
الأعلى للقضاء باء باء تباشر المحكمة العليا اختصاصاتها من خلال دوائر متخصصة بحسب الحاجة، تؤلف كل منها من ثلاثة قضاة باستثناء الدائرة الجزائية التي تتظر في الأحكام

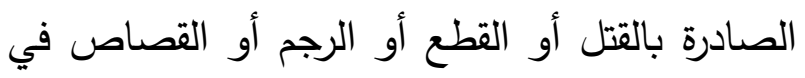

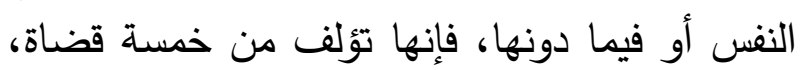

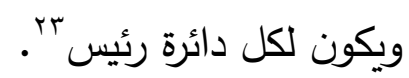

ومن أبرز اختصاصات المحكمة العليا مايلي: 1

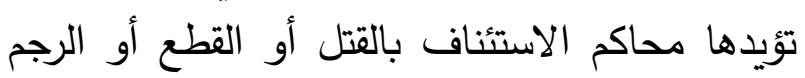
أو القصاص في النفس أو فيما دونها.

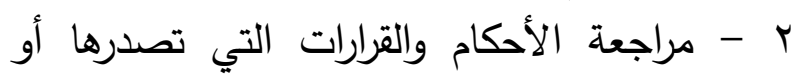

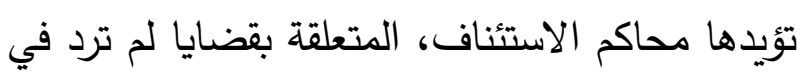

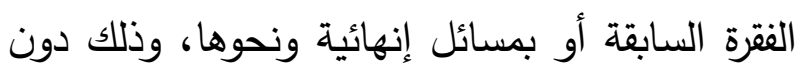

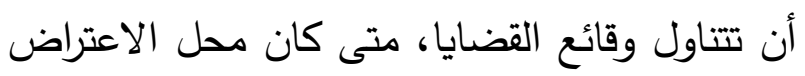

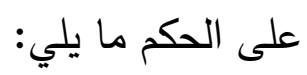

وإنهاء خدمة وغير ذلك، وفقًا للقواعد والإجراءات المقررة، وذلك بما يضمن استقلال القضاة.

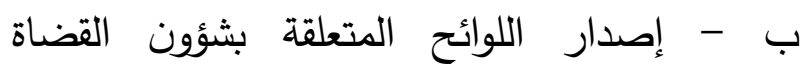
الوظيفية بعد موافقة الملك عليها. ج - إصدار لائحة للتفتيش القضائي.

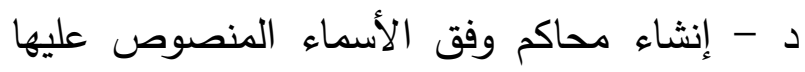

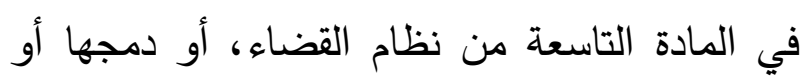

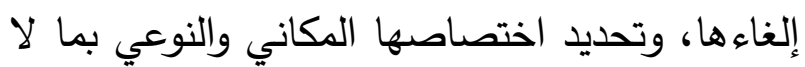

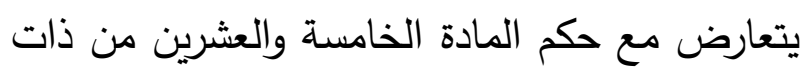
النظام، وتأليف الدوائر فيها.

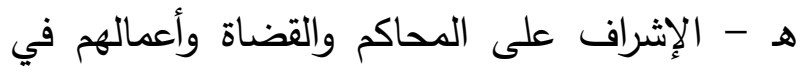
الحدود المبينة في هذا النظام. و - تسمية رؤساء محاكم الاستئناف ومساعديهم من فن مناف بين قضاة محاكم الاستئناف، ورؤساء محاكم الدرجة الأولى ومساعديهم. ز - إصدار قواعد تتظم اختصاصات وصلاحيات رؤساء المحاكم ومساعديهم. ح - إصدار قواعد تبين طريقة اختيار القضاة، وإجراء ات وضوابط تفريغهم للدراسة. ط - تنظيم أعمال الملازمين القضائيين. ي - تحديد الأعمال القضائية النظيرة المطلوبة النية النين لشغل الدرجات القضائية. ك - رفع ما يراه من المقترحات ذات الصلة الصات بالاختصاصات المقررة له. ل - إعداد تقرير شامل في نهاية كل عام يتضمن الإنجازات التي تحققت والمعوقات ومقترحاته بشأنها ورفعه إلى الملك ‘r. 
د- إذا كان الحكم مبنيَّا على حكم صادر من إحدى المحاكم ثم ألغِيَ هذا الحكم. دان.

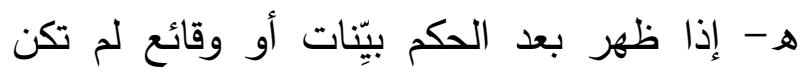
معلومة وقت المحاكمة، وكان من شأن هذه البيّنات

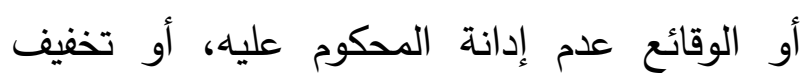

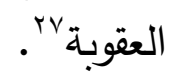

\section{محاكم الاستئناف}

محاكم الاستئناف هي محاكم الدرجة الثانية في المملكة العربية السعودية، ويكون في كل منطقة محكمة استئناف أو أكثر، وتباشر أعمالها من خلال دوائر متخصصة، تؤلف كل دائرة منها من ثلاثثة قضاة، باستثناء الدائرة الجزائية التي تتظر في قضايا القتل والقطع والرجم والقصاص في النفس أو فيما دونها فتؤلف من خمسة قضاة، ولا تقل درجة القاضي في محكمة الاستئناف عن درجة قاضي فولي استئناف، ويكون لكل دائرة رئيس. كما يجوز إنشاء دائرة استئناف متخصصة أو أكثر في المحافظات

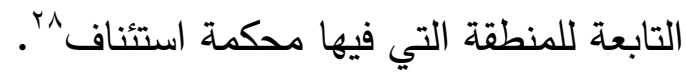
وتشمل دوائر الاستئناف الدوائر التالية: ا 1 r - الدوائر الجزائية. ب - دوائر الأحوال الشخصية.

$$
\text { ـ - - الدوائر التجارية. }
$$

ومن أبرز اختصاصات محاكم الاستئناف ما يلي:

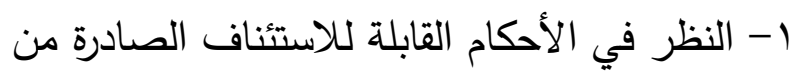
محاكم الدرجة الأولى، وتحكم بعد سماع أقوال

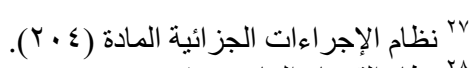

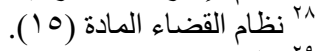

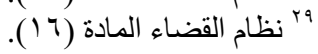

أ - مخالفة أحكام الثريعة الإسلامية وما يصدره ولي الأمر من أنظمة لا تتعارض معها. ب - صدور الحكم من محكمة غير مشكلة تشكيلً سليمًا طبقًا لما هو منصوص عليه في الأنظمة. ج - صدور الحكم من محكمة أو دائرة غير مختصة. د - الخطأ في تكييف الواقعة، أو وصفها وصفًا غير سليم ب - تقرير مبادئ عامة في المسائل المتعلقة بالقضاء. ع - النظر في المسائل التي تتص الأنظمة على

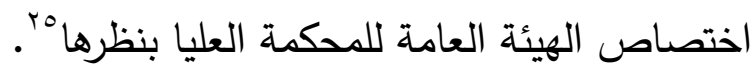
0- النظر في الطعون على الأحكام الصادرة بطبلان حكم التحكيم بr '. 7- النظر في طلبات إعادة النظر في الأحكام

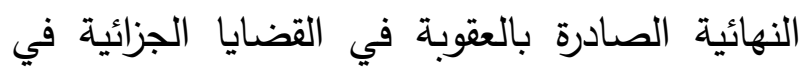
الأحوال التالية: - التهاله أ- إذا حكم على المتهم في جريمة قتل ثمُ وُجد المُلََّعَى قتله حيَّا. ب- إذا صدر حكم على شخص من أجل واقعة، ثم صدر حكم على شخص آخر من أجل الواقعة نفسها، وكان بين الحكمين تناقض يُفْهَمْ منه عدم إدانة أحد المحكوم عليهما. ج- إذا كان الحكم قد بُنِيَ على أوراق ظهر بعد الحكم تزويرها، أو بُنيَي على شهادة قضي - من الجهة المختصة بعد الحكم - بأنها شهادة زور • بردي

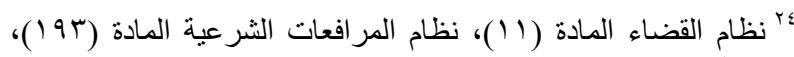

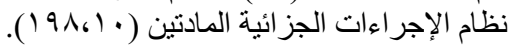
ro ro نظام القضاء الإجراءة المادة (1T) (1).

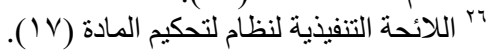


ه- النظر في طلب تتحي المحكم إذا تم رفضها من

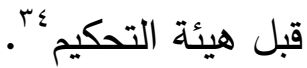

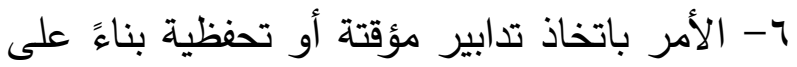
طلب أحد طرفي التحكيم قبل البدء في إجراءات التحكيم أو بناءً على طلب هيئة التحكيم أثناء سير

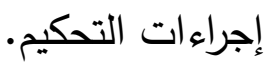
- الأمر بالإنابة القضائية بناءً على طلب هيئة التحكيم ^- تحديد أتعاب المحكمين إذا لم يتم الاتفاق بين

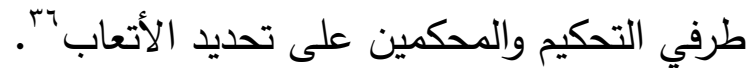
9- تعينُ محكمٍ مرجح إذا تشعبت آراء هيئة التحكيم ولم يكن مدكناً حصول الأغلبية ولم تختر هيئة

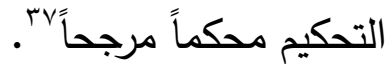

• 1- الحكم بإبطال حكم التحكيم إذا تضمن ما يخالف أحكام الشريعة الإسلامية والنظام العام في النيال

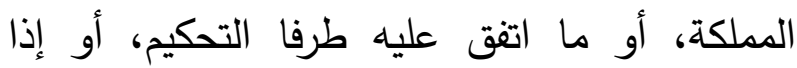
وجدت أن موضوع النزاع من المسائل التي لا يجوز

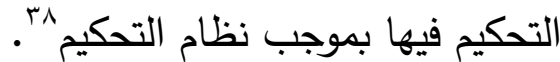

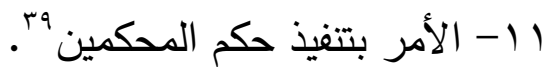

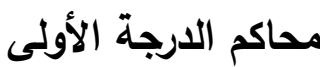
تنشأ محاكم الدرجة الأولى في المناطق والمحافظات

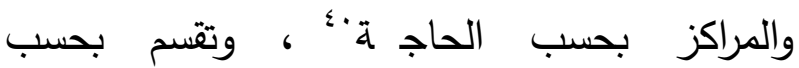
الاختصاص إلى المحاكم التالية:

(10 (10) نظام التحكيم المادة)

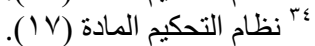

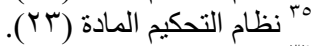

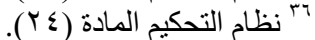

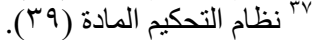

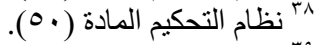

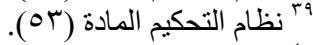
•" نظام القضاء المادة (1) (1).
الخصوم، وفق الإجراءات المقررة في نظام المرافعات الشرعية ونظام الإجراءات الجزائية“’”.

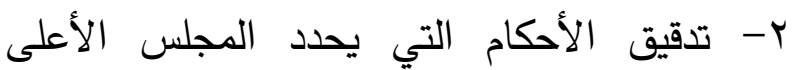
للقضاء الاكتفاء بتدقيقها، ومنها:

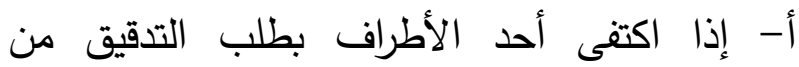

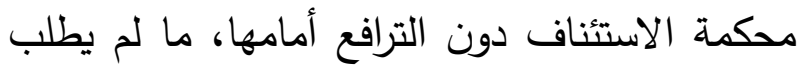

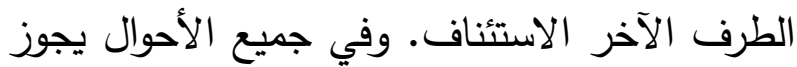
لمحكمة الاستئناف نظر الدعوى مرافعة إذا رأت ذلك. ب- إذا كان المحكوم عليه ناظر وقف أو وصيًا أو

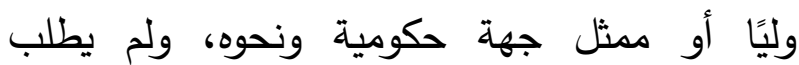

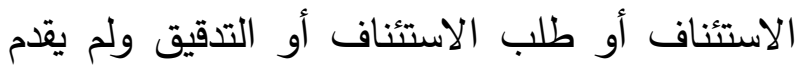
مذكرة الاعتراض خلال المدة المقررة نظامًا، أو كان

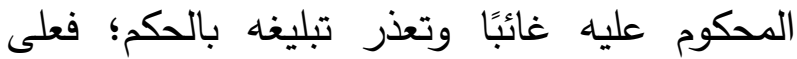
المحكمة أن ترفع الحكم إلى محكمة الاستئناف

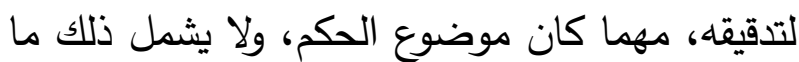
يأتي: - القرار الصادر على الهيئة العامة للولاية على أموال القاصرين ومن في حكمه من المحكمة

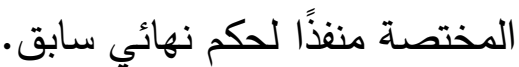

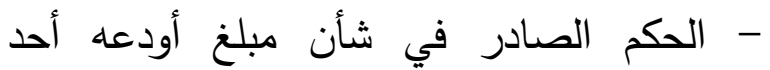

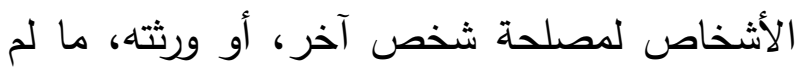

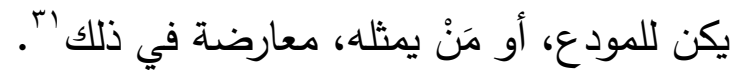
r- نظر دعوى بطلان حكم التحكيم بr.

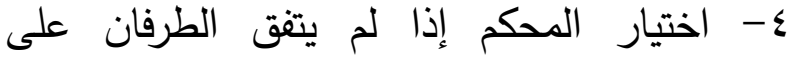

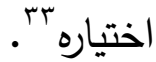

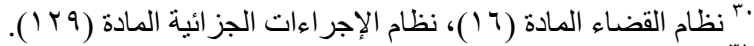

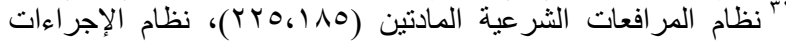
الجز ائية المادة (9 ب ( ) ).

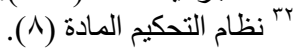


ج - الدعاوى الناشئة عن حوادث السير وعن المخالفات المنصوص عليها في نظام المرور ولائحته التنفيذية؛ ؛ r- تختص المحكمة العامة في المحافظة أو المركز اللذين ليس فيهما محكمة متخصصة بنظر جميع الدعاوى والقضايا والإثباتات الإنهائية وما في حكمها لخهائ الداخلة في اختصاص تلك المحكمة المتخصصة، وذلك ما لم يقرر المجلس الأعلى للقضاء خلاف ذلك

\section{ثانياً- المحاكم الجزائية:}

تؤلف المحاكم الجزائية من دوائر متخصصة هي: أ- دوائر قضايا القصاص والحدود. ب - دوائر القضايا التعزيرية. ج - دوائر قضايا الأحداث. وتشكل كل دائرة من ثلاثة قضاة، باستثناء القضايا التي يحددها المجلس الأعلى للقضاء فينظرها قاضٍ فرد

ومن أبرز اختصاصات المحاكم الجزائية: ا - الفصل في جميع القضايا الجزائيةء؛ r- النظر في قضايا الحق الخاص لمن لحقه ضرر من الجريمة - ولوارثه من بعده - أمام المحكمة

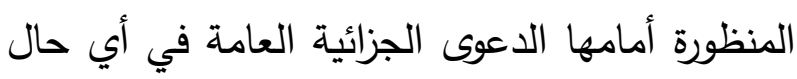
كانت عليها الدعوى ^؛

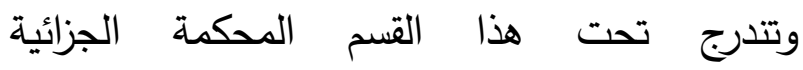
المتخصصة في قضايا الإرهاب، والتي تقع في مدينة

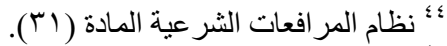

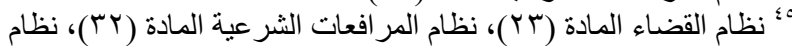

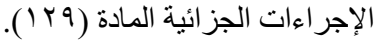

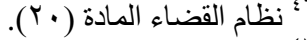

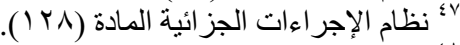

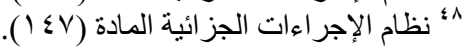

أولاًا- المحاكم العامة: تؤلف المحاكم العامة في المناطق من دوائر متخصصة، يكون من بينها دوائر للتفيذ ولإثباتات الإنهائية وما في حكمها - الخارجة عن اختصاصات المحاكم الأخرى وكتابات العدل - الإلهات

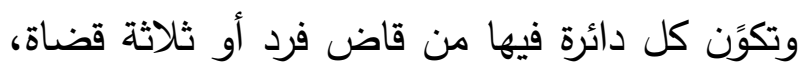

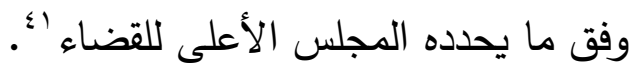
كما تؤلف المحكمة العامة في المحافظة أو لون المركز من دائرة أو أكثر ، وتكون كل دائرة من قاضٍ

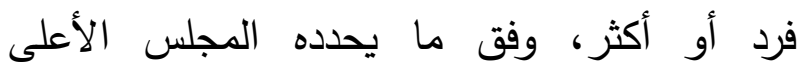
للقضاء. ويحدد المجلس الأعلى للقضاء القضايا التي تختص بنظرها المحكمة العامة المكونة من

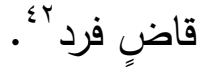

ومن أبرز اختصاصات المحاكم العامة: ا- - نظر جميع الدعاوى والقضنايا والإثباتات الإنهائية وما في حكمها الخارجة عن اختصاص المحاكم الأخرى وكتابات العدل وديوان المظالم، ولها بوجه خاص النظر في الآتي: أ - الدعاوى المتعلقة بالعقار، من المنازعة في الدي الملكية، أو حق متصل به، أو دعوى الضرر من بن الضعال العقار نفسه أو من المنتفعين باه، أو دعوى قيام

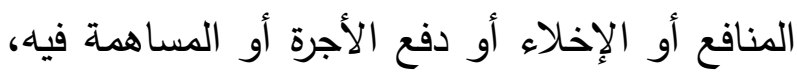

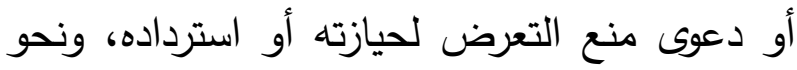
ذلك، ما لم ينص النظام على خلاف ذلك. ب - إصدار صكوك الاستحكام بـ بملكية العقار أو

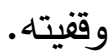

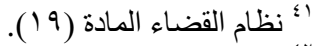

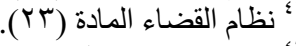
r الاستحكام: هو طلب صلك بإنبات تملك عقار في غير فير مواجهة خصم

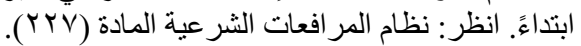


إحدى الاتفاقيات الواردة في مرفق الاتفاقية الدولية

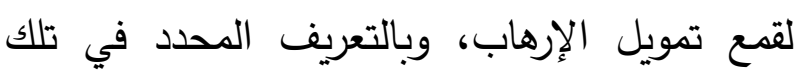

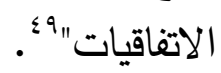
ومن أبرز اختصاصات هذه المحكمة: 1- النظر في قضايا الإرهاب التي تهدف إلى الى: أ - تغيير نظام الحكم في المملكة. ب - تعطيل النظام الأساسي للحكم أو بعض مواده.

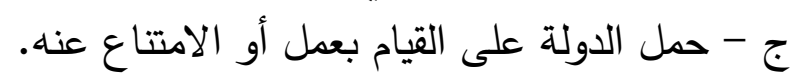
د - الاعتداء على السعوديين في الخارج.

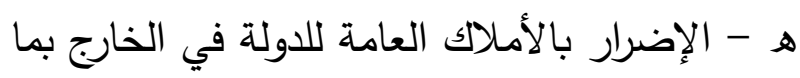

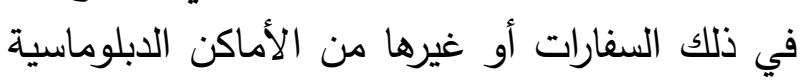
أو القنصلية التابعة لها.

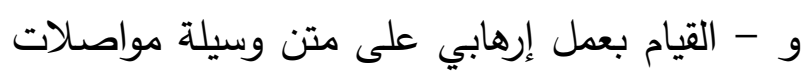
مسجلة لدى المملكة أو تحمل علمها.

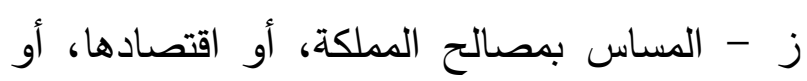
أمنها الوطني أو الاجتماعي لـ r- الموافقة من عدمها على تمديد توقيف المتهم في الواعتي

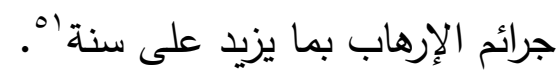

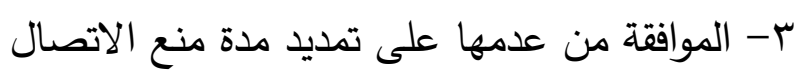

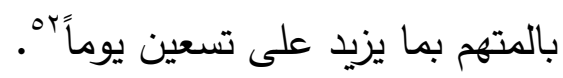

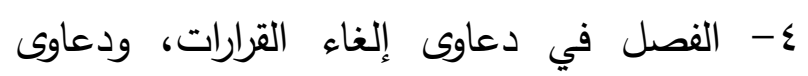
التعويض، المتعلقة بتطبيق أحكام نظام جرائم الإرهاب وتمويله. 0. - النظر في جرائم غير الإرهاب إذا كانت

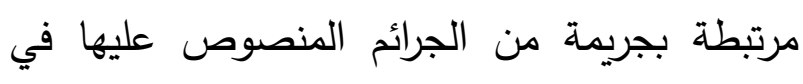
نظام جرائم الإرهاب وتمويله، فنتولى المحكمة عند

9؛ نظام جر ائم الإر هاب وتمو يله المادة (1).

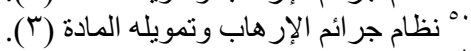

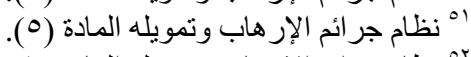

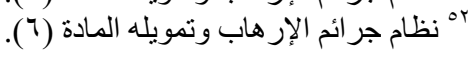

الرياض، ويقع في اختصاصها النظر في جرائم

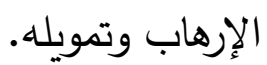

ويقصد بالجريمة الإرهابية هنا ما بينته المادة (الأولى) من نظام جرائم الإرهاب وتمويله، وهي:

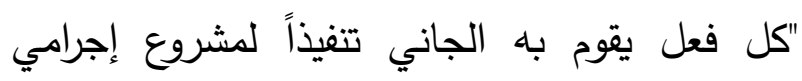

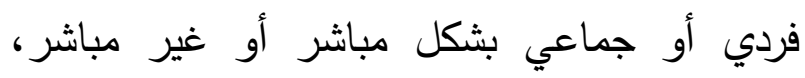

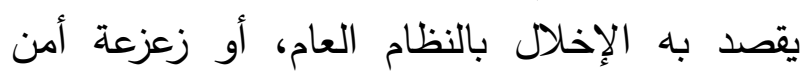

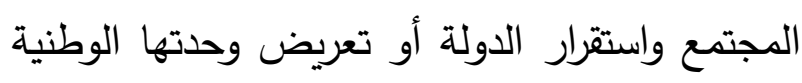

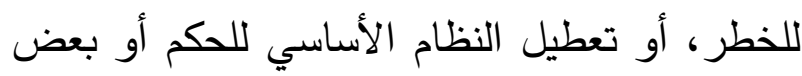
مواده، أو الإنساءة إلى سمعة الدولة أو مكانتها، أو الو الؤاس إلحاق الضرر بأحد مرافق الدولة أو مواردها

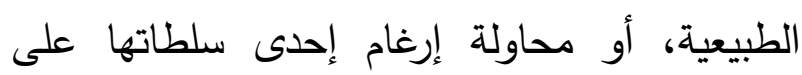

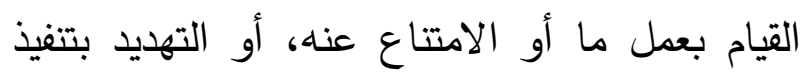
أعمال تؤدي إلى المقاصد المذكورة أو التحريض المثاع عليها".

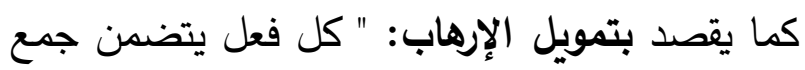
أموال، أو تقديمها، أو أخذها، أو تخصيصها، أو أو لتون

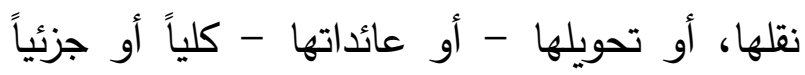
لأي نشاط إرهابي فردي أو جماعي، منظم أو أو غير أو أونيا

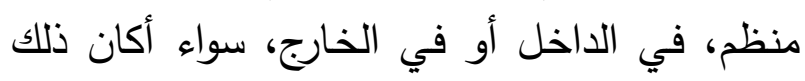

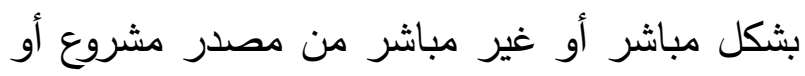

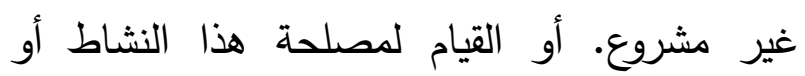

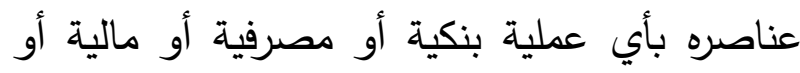
تجارية، أو التحصيل مباشرة أو بالوساطة على أموال

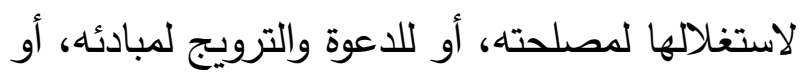

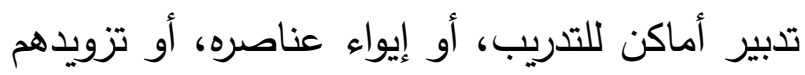
بأي نوع من الأسلحة أو المستندات المزورة، أو تقديم ألتيم أي وسيلة مساعدة أخرى من وسائل الدعم والتمويل مع العلم بذلك؛ وكل فعل يشكل جريمة في نطاق ولت التربل 
و - تزويج من لا ولي لها، أو من عضلها أولياؤها.

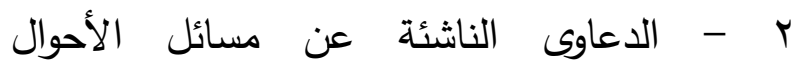

الشخصية.

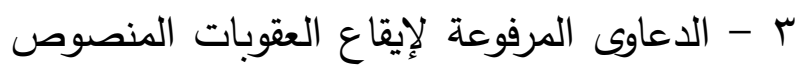
عليها في نظام الهيئة العامة للولاية على أموال

$$
\begin{aligned}
& \text { القاصرين ومن في حكمه بـه } \\
& \text { رابعاً: المحاكم التجارية: }
\end{aligned}
$$

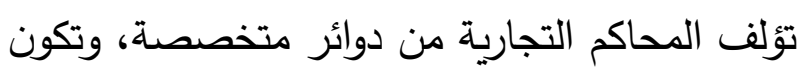
كل دائرة من قاضٍ فرد أو أكثر، وفق ماكت ما يحدده

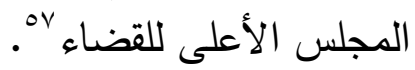

وتختص المحاكم التجارية بالنظر في الآتي: أ - جميع المنازعات التجارية الأصلية والتبعية التي التي التياتي تحدث بين التجار . ب - الدعاوى التي تقام على التاجر بسبب أعماله التجارية الأصلية والتبعية. ج - المنازعات التي تحدث بين الشركاء في الشركات.

د - جميع الدعاوى والمخالفات المتعلقة بالأنظمة

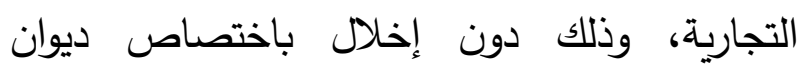

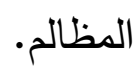
هـ - دعاوى الإفلاس والحجر على المفلسين ورفعه عنهم و - المنازعات التجارية الأخرى همئ. خامساً- المحاكم العمالية:

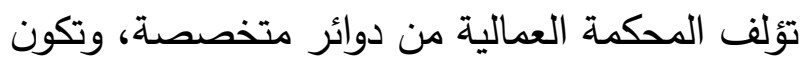
كل دائرة من قاضٍ فرد أو أكثر، وفق مالئ ما يحدده

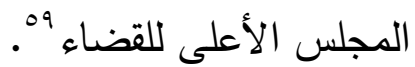

الجزائية المتخصصة الفصل في جميع الجرائم الموجهة إلى المتهم، ما لم تفرز أوراق مستقلة لهذه

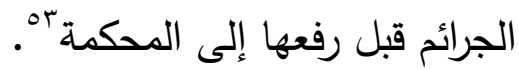

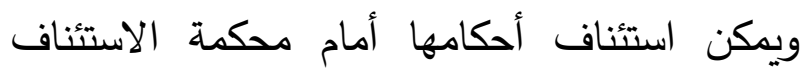
المتخصصة، ويجوز الاعتراض على أحكامها أمام دائرة متخصصة في المحكمة العلياءه

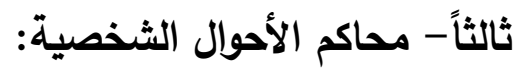

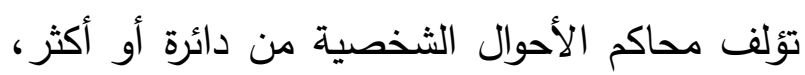

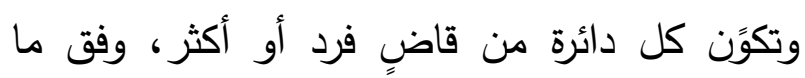

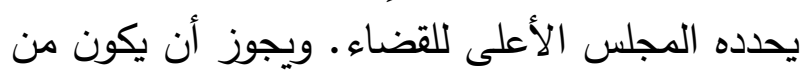
بينها دوائر متخصصة بحسب الحاجة الهب ومن أبرز اختصاصاتها النظر فيما يلي: 1 - جميع مسائل الأحوال الثخصية، ومنها:

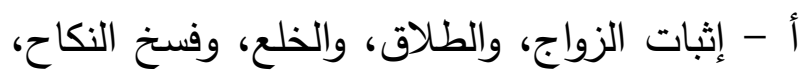
والرجعة، والحضانة، والنفقة، والزيارة.

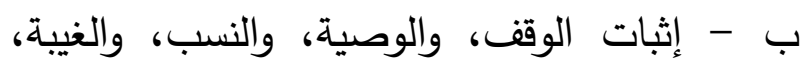
والوفاة، وحصر الورثة. ج- الإرث، وقسمة التركة بما فيها العقار إذا كان أنهان فيها نزاع، أو حصة وقف أو وصية، أو قاصر، أو أو أو غائب. د - إثبات تعيين الأوصياء، وإقامة الأولياء والنظار ،

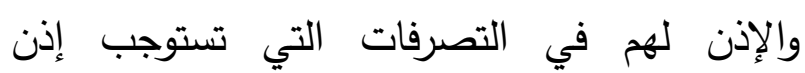

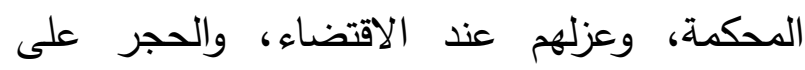
السفهاء، ورفعه عنهم، وتحدد لوائح نظام المرافعات

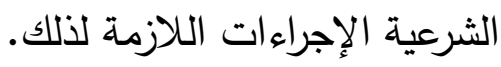
هـ - إثبات توكيل الأخرس الذي لا يعرف القراءة والكتابة. 
ويتألف ديوان المظالم من رئيس بمرتبة وزير ، ونائب

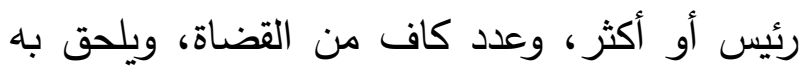
العدد اللازم من الباحثين والفنيين والإداريين

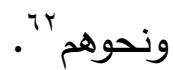

ويتولى مجلس القضاء الإداري بالنسبة لديوان

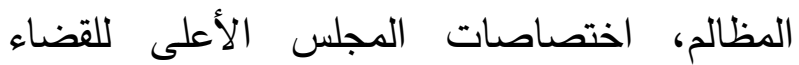

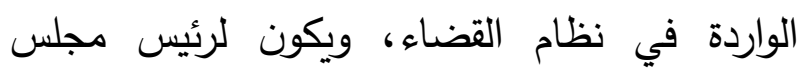

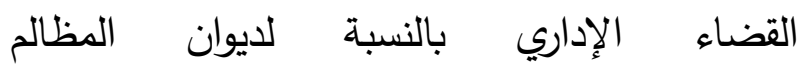
الاختصاصات المقررة لرئيس المجلس الأعلى لألى لإن

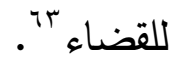
وتتدرج تحت ديوان المظالم المحاكم التالية: 1- المحكمة الإدارية العليا. r- ب البحم الاستئناف الإدارية.

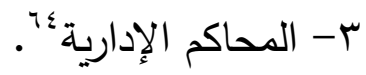
ويجوز لمجلس القضاء الإداري إحداث محاكم

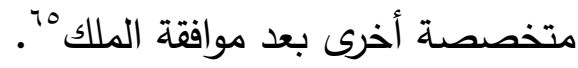
أولاً: المحكمة الإدارية العليا:

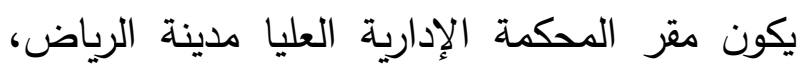
وتؤلف من رئيس وعدد كاف من القضاة بدرجة رئيس محكمة استئناف. ويكون للدحكمة الإدارية

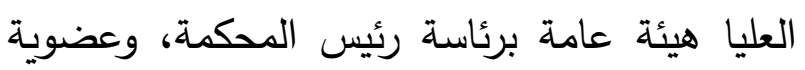
جميع قضاتها"

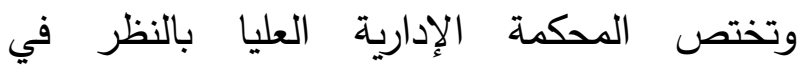
الاعتراضات على الأحكام التي تصدرها محاكم
وتختص المحاكم العمالية بالنظر في الآتي: أ - المنازعات المتعلقة بعقود العمل والأجور والحقوق وإصابات العمل والتعويض عنها.

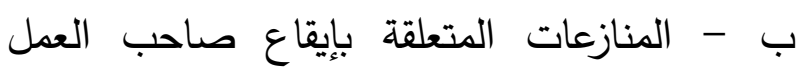

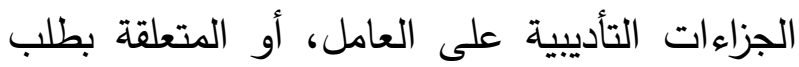
الإعفاء منها. ج - الدعاوى المرفوعة لإيقاع العقوبات المنصوص الإعلاء عليها في نظام العمل. د - المنازعات المترتبة على الفصل من العمل. هـ - شكاوى أصحاب العمل والعمال الذين لم تقبل العبل العبل اعتراضاتهم ضد أي قرار صادر من أي جهاز

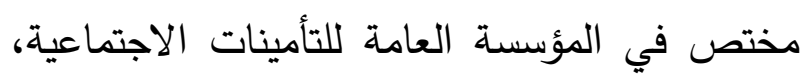
يتعلق بوجوب التسجيل والاشتراكات أو التعويضات. و - المنازعات المتعلقة بالعمال الخاضعين لأحكام التحات التعات نظام العمل، بمن في ذلك عمال الحكومة. ز - المنازعات الناشئة عن تطبيق نظام العمل

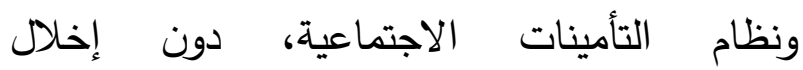
باختصاصات المحاكم الأخرى وديوان المظالم" .

ديوان المظالم

ديوان المظالم هو هيئة قضاء إداري مستقلة، يرتبط مباشرة بالملك، ويكون مقره مدينة الرياض، ويتمتع

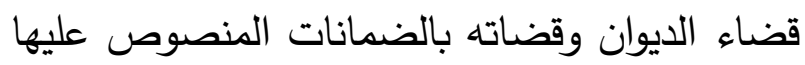

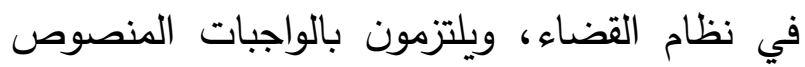

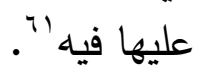

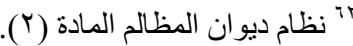

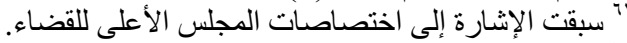

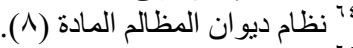

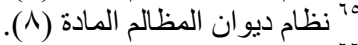

17 نظام ديو ان المظالم المادة (• (1).

99 نظام القضاء المادة (Yr)

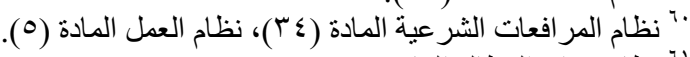

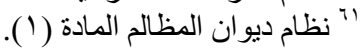


الاختصاص، أو وجود عيب في الثكل، أو عيب في السبب، أو مخالفة النظم واللوائح، أو الخطأ في تطبيقها أو تأويلها، أو إساءة استعمال السلطة، بما في ذلك القرارات التأديبية، والقرارات التي تصدياءوهاتوها اللجان شبه القضائية والمجالس التأديبية. وكذلك القرارات التي تصدرها جمعيات النفع العام - وما في وكاني حكمها - المتصلة بنشاطاتها، ويعد في حكم القرار الإداري رفض جهة الإدارة أو امتناعها عن اتخاذ قرار كان من الواجب عليها اتخاذه طبقًا للأنظمة الإدارة واللوائح. r- دعاوى التعويض التي يقدمها ذوو الثأن عن قرارات أو أعمال جهة الإدارة. ع- الدعاوى المتعلقة بالعقود التي تكون جهة الإدارة

طرفا فيها. 0- الدعاوى التأديبية التي ترفعها الجهة المختصة. 7- المنازعات الإدارية الأخرى. V- طلبات تنفيذ الأحكام الأجنبية وأحكام المحكمين الأدين الأجنبية محاكم التنفيذ الأصل في تتفيذ الأحكام أن تتولاه دوائر التنفيذ في كل محكمة عامة - ويجوز تأليف أكثر من دائرة عند الحاجة. كما يتولى القاضي الفرد - في

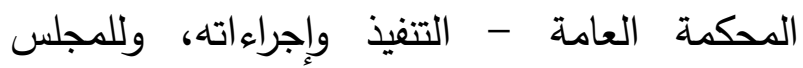
الأعلى للقضاء - عند الحاجة - إحداث محاكم

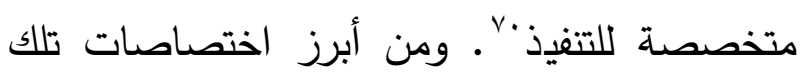

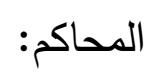

9" نم نقل طلبات تنفيذ الأحكام الأجنبية وأحكام المحكمين الأجنبية إلى اختصاص نظام التتفيذ.

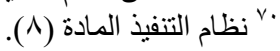

الاستئناف الإدارية، إذا كان محل الاعتراض على الحكم ما يأتي: 1

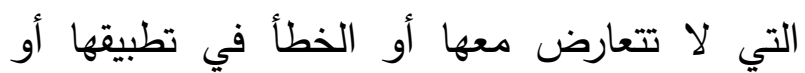
تأويلها، بما في ذلك مخالفة مبدأ قضائي تقرر في حكم صادر من المحكمة الإدارية العليا. r- صدوره عن محكمة غير مختصة. r- صدوره عن محكمة غير مكونة وفقًا للنظام. ع- الخطأ في تكييف الواقعة، أو في وصفها. 0- فصله في نزاع خلافًا لحكم آخر سبق أن صدر

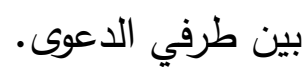

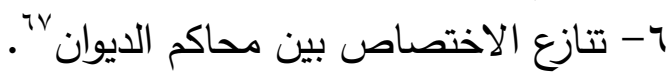
ثانياً: محاكم الاستئناف الإدارية: تتولى محاكم الاستئناف الإدارية النظر في الأحكام

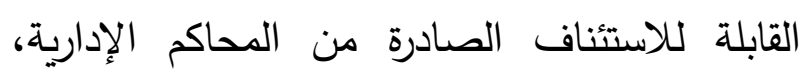
وتحكم بعد سماع أقوال الخصوم وفق الإجراءات المقرة نظامًا ثالثاً: المحاكم الإداريـة: تختص المحاكم الإدارية بالفصل في الآتي: ا- الدعاوى المتعلقة بالحقوق المقرة في نظم الإدانه

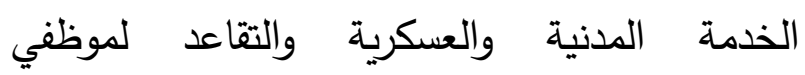
ومستخدمي الحكومة والأجهزة ذوات الشخصية المعنوية العامة المستقلة أو ورثتهم والمستحقين عنهم. r- دعاوى إلغاء القرارات الإدارية النهائية التي يقدمها ذوو الشأن، متى كان مرجع الطعن عدم

ע" نظام ديوان المظالم المادة (1). (1). نظام المر افعات أمام ديوان المظالم

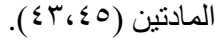

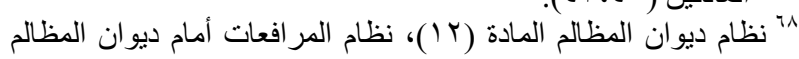

المادة (r) ع (الم) 
1- مراقبة أعمال المحاكم الشعبية المحلية وكذلك

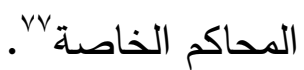

r- الإشراف على مجلس نواب الثعب الوطني

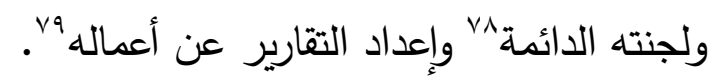
ب- الفصل في القضايا التالية:

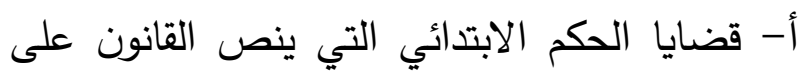
اختصاص المحكمة الثعبية العليا بنظرها أو التي لتي لئي تراها المحكمة داخلة ضمن اختصاصها.`. ب- قضايا الحكم الابتدائي الإدارية المهمة والمعقدة

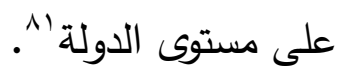
ج- قضايا الحكم الابتدائي الددنية التي لها تأثير

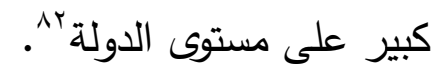
د- قضايا الحكم الابتدائي الجنائية الكبرى على لـى على

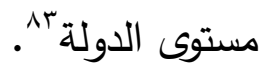
هـ قضايا إعادة المحاكمات التي يتم تقديمها وفقاً

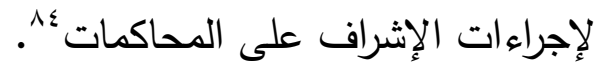

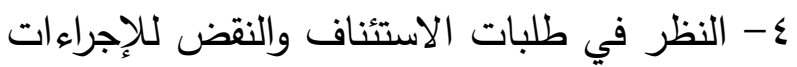

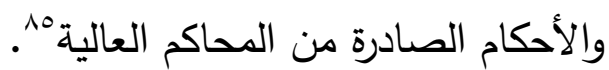

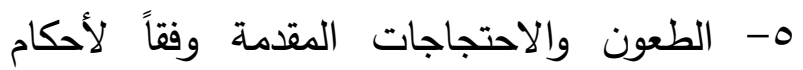

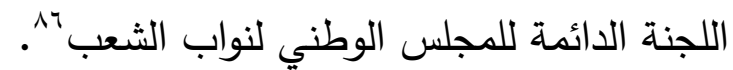

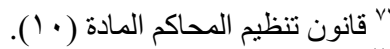

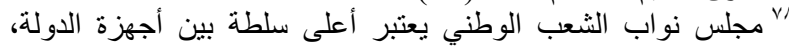
ويمارس مجلس نواب الشعب الوطني ولجنته الدئل الدائمة السلطة التشريعية للاولة.

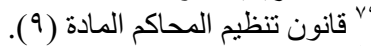

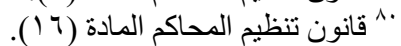

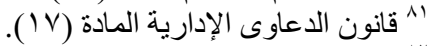

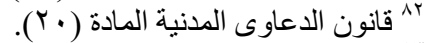

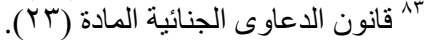

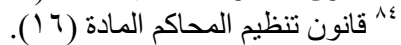

י101 قانون تنظيم المحاكم المادة (7 (1) ).

ז^ قانون تنظيم المحاكم المادة (7 (1) ).
1- التتفيذ الجبري والإشراف عليه، فيما عدا الأحكام

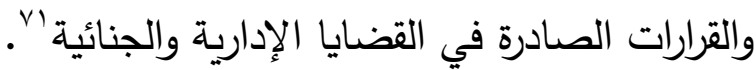
r- الفصل في منازعات التنفيذ مهما كانت قيمتها،

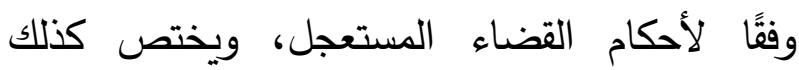
بإصدار القرارات والأوامر المتعلقة بالتنفيذ، وله الأمر الماه بالاستعانة بالشرطة أو القوة المختصة، وكذلك الأمر

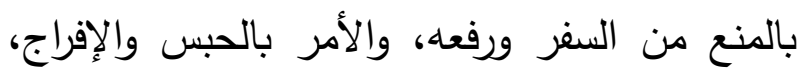
والأمر بالإفصاح عن الأصول، والنظر في دعوى والإل والإن

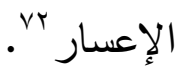

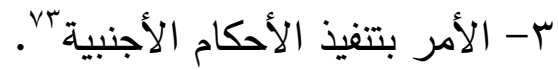
محاكم جمهورية الصين الثعبية

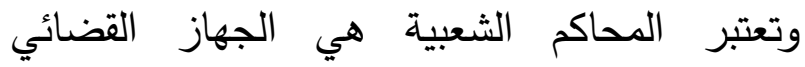

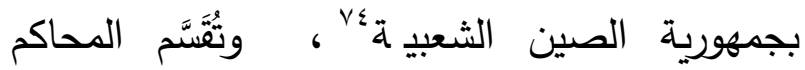
الثعبية على النحو التالي: التعين 1- المحكمة الشعبية العليا. r- المحاكم الشعبية المحلية.

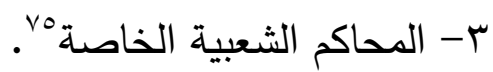
أولاً: المحكمة الثعبية العليا

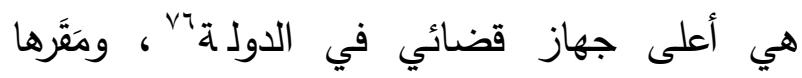

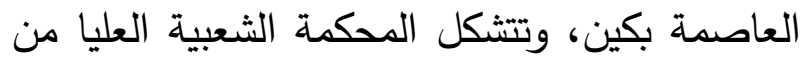
رئيس ونائب للرئيس وعدد من الهيئات المتخصصة ونئة في القضايا المدنية والتجارية والإدارية والجنائية

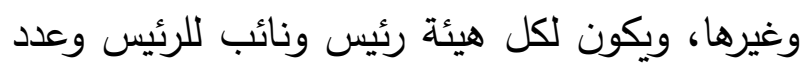

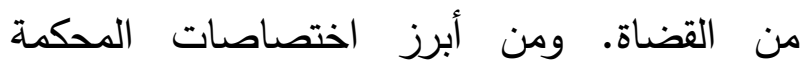
الشعبية العليا ما يلي: منئ

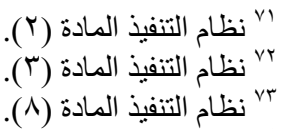

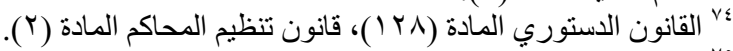

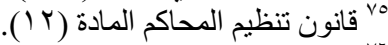

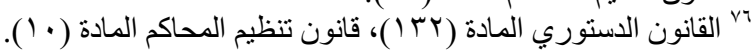


حسب ما ينص عليه القانون، ومن اختصاصاتها

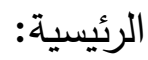

ا- النظر في قضايا الحكم الابتدائي التي تقع داخل إنل نطاق اختصاصها وفقاُ للقانون، ومنها:

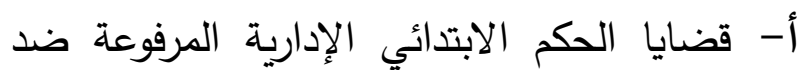
دوائر مجلس الدولة أو الحكومات الشعبية المحلية

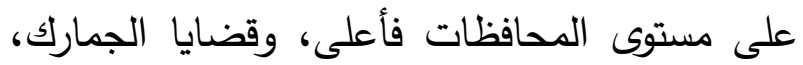

والقضايا الكبيرة والمهمة داخل نطاق ولايتها به . ب- قضايا الحكم الابتدائي المدنية الهامة ذات العلاقة بالأجانب، والقضايا الهامة ذات التأثير الكبير في نطاق ولايتها، والقضايا التي تحيلها المحكمة العليا إلى المحاكم المتوسطة لتنظرهاء؟ ج- قضايا الحكم الابتدائي الجنائية المتعلقة بأنشطة

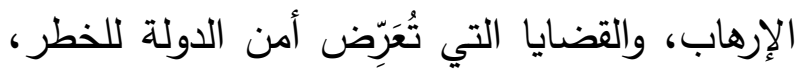
وكذلك القضايا الجنائية التي يمكن أن يُحكم فيها تهرها بالسجن المؤبد أو الإعدام '90.

د- قضايا الحكم الابتدائي التي تُحيلها المحاكم الابتدائية إليها هـ - قضايا الحكم الابتدائي التي تحيلها إليها المحكمة الثعبية العليا أو المحكمة الشعبية العالية في نطاق ولايتها.

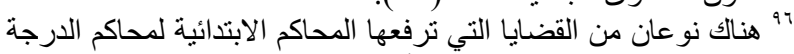

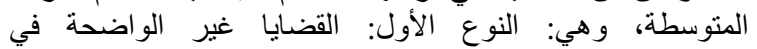

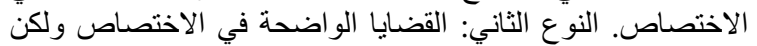

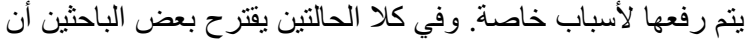

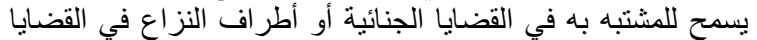

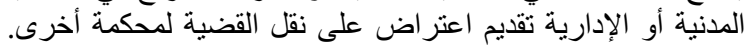

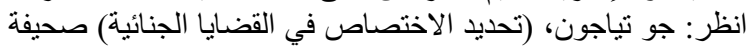

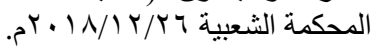

7- تدقيق قضايا الإعدام التي ترفعها المحكمة الشعبية العالية إليهاءئ. V- التقسير القانوني للإشكالات المتعلقة بالأعمال القضائية ^^^.

ثانياً: المحاكم الشعبية المحلية تتقسم المحاكم الثعبية المحلية إلى: 1- المحكمة الشعبية الابتدائية. r- المحكمة الشعبية المتوسطة.

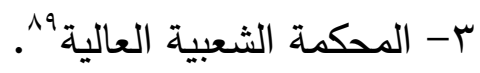
(أ) المحاكم الثعبية الابتدائية وهي الأقل درجةً من أنواع المحاكم الشعبية، ومن الأن اختصاصاتها الرئيسية:

1- النظر في قضايا الحكم الابتدائي باستثناء ما ينص عليه القانون ·". r- القيام بتوجيه أعمال الوساطة للجان الوساطة الشعبية ' الشيام

كما يجوز للمحاكم الشعبية الابتدائية إنشاء عدة هيئات شعبية قضائية كممثلة لها، وفقاً لحاجة المنطقة أو السكان أو في حالات معينة، ويكون لهذهاته

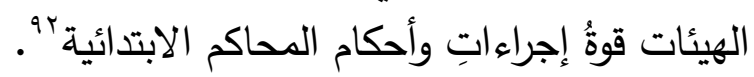
(ب) المحاكم الثعبية المتوبطة تعتبر المحاكم الشعبية المتوسطة من محاكم الدرجة الثانية، إلا أنها قد تنظر بعض القضايا الابتدائية

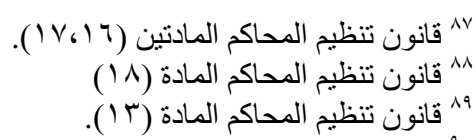

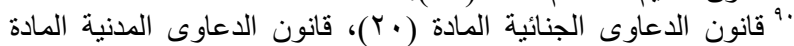

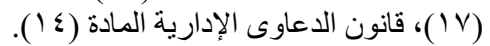

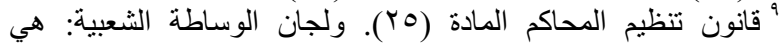

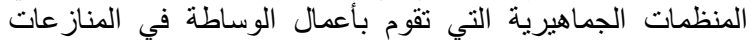

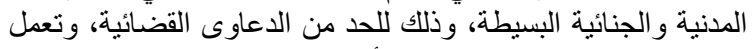
تحت إثر اف الحكومات الشعبية الأساسية، و المحاكم الشعبية. لألية. r فانون تنظيم المحاكم المادة (T) (Y). 
0- تدقيق قضايا الحكم الابتدائي التي حكمت فيها

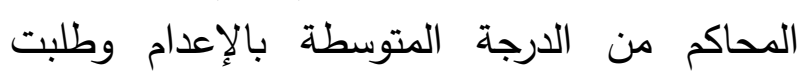

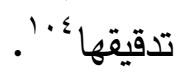

1- مراقبة سير المحاكمات في المحاكم على في

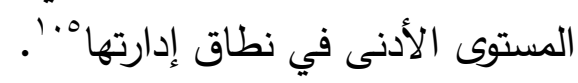

ثالثاً: المحاكم الخاصة المحاكم الخاصة تشمل: المحاكم العسكرية والمحاكم

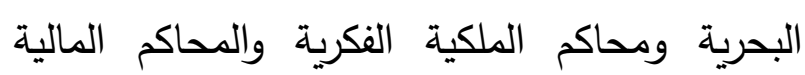

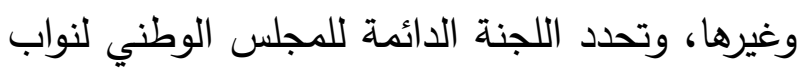

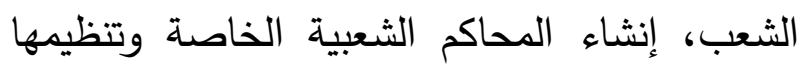

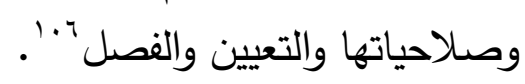
(أ) المحاكم العسكرية المحكمة العسكرية هي محكمة خاصة أنشأتها الدولة

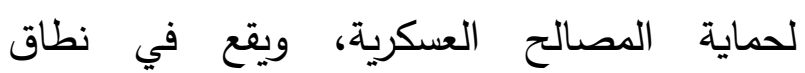
اختصاصها بشكل أساسي القضايا الجنائية داخل الجيش، وتستمد سلطاتها من السلطة القضائية للدولة'•، إلا أن المحكمة الشعبية العليا قد أصدرت

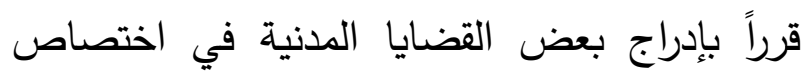

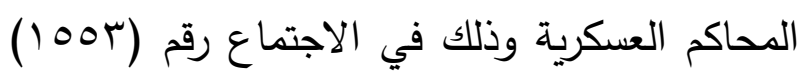
في •r أغسطس Y Y • Y. وتم تطبيق القرار ابتداءً

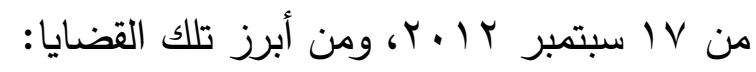
1- القضايا التي يكون فيها الطرفان أشخاص أنسان عسكريون أو وحدات عسكرية، باستثناء ما ينص الطنان الفياصن

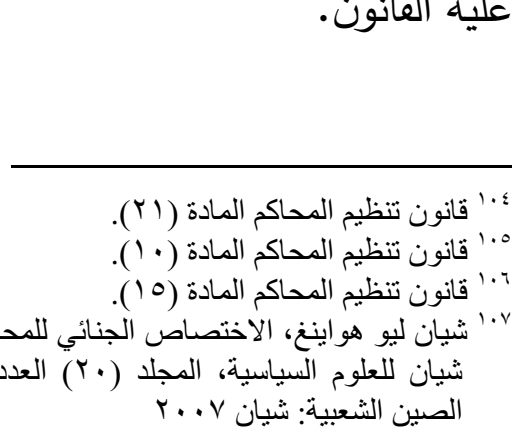

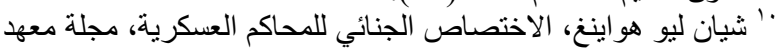

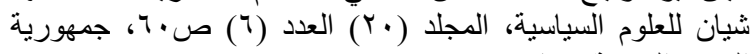

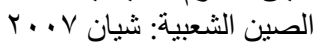
عليه القانون.

r- النظر في طلبات الاستئناف والطعن ضد إنداء

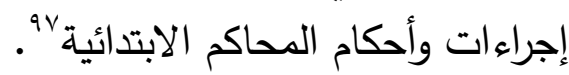

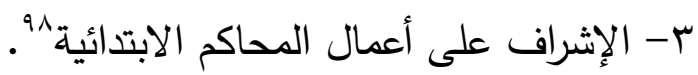
(ج) المحاكم الثعبية العالية وهي أعلى درجةً من درجات المداكية المحاكم الشعبية المحلية، ومن اختصاصاتها الرئيسية:

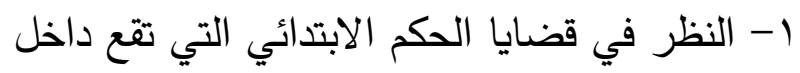
نطاق اختصاصها وفقاُ للقانون، ومنها: أ- قضايا الحكم الابتدائي الإدارية الكبرى والمعقّدة داخل نطاق ولايتها ب- قضايا الحكم الابتدائي المدنية التي لها تأثير

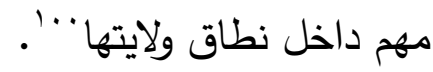

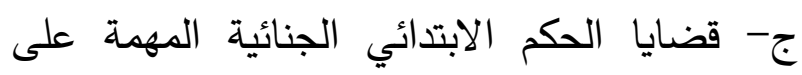

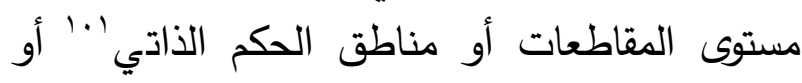

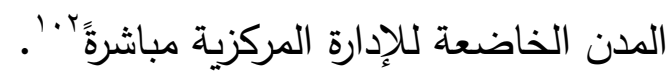
r- قضايا الحكم الابتدائي التي تتقل من المحاكم على المستوى الأدنى بـ".

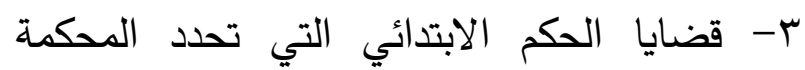
الشعبية العليا أنها من اختصاص المحاكم الشعبية

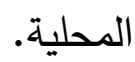
ع- النظر في طلبات الاستئناف والطعن ضد أحكام وقرارات المحاكم على المستوى الأدنى.

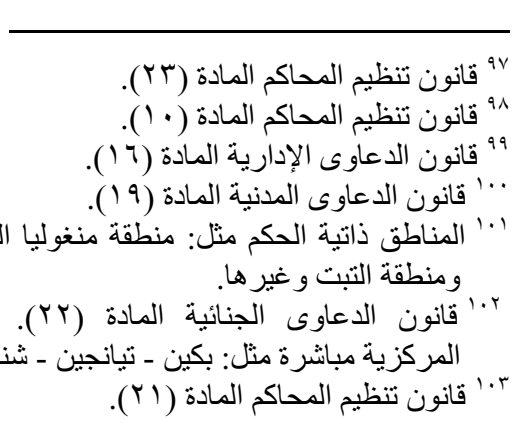


بشأن "اختصاصات المحاكم البحرية"، وذلك بالإشارة

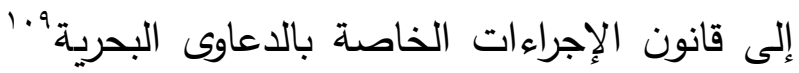
ومن اختصاصاتها الرئيسية: 1- قضايا الاعتداء على الحقوق في مجال الشؤون البحرية:

ومنها: قضايا تصادم السفن والتعويض، وقضايا التعويض عن الخسائر الناتجة عن صدم السفن ولنابن لأبنية ومرافق في البحر ، وقضايا المنازعات الناشئة

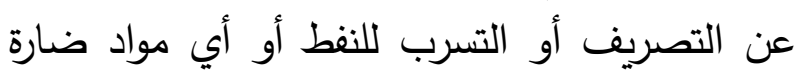

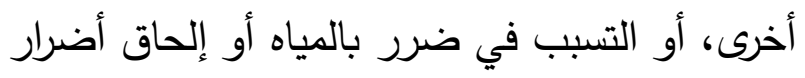

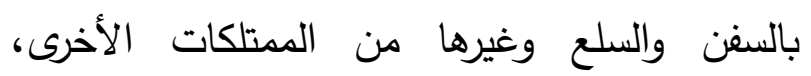

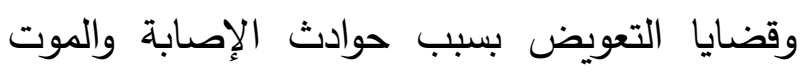
التي تحدث أثناء أعمال النقل في البحر، وقضائ التصايا المنازعات في المسؤولية المتعلقة بتشغيل السفينة التي تُضر بالصيد ومرافق تربية الأحياء المائية، وقضايا المنازعات المتعلقة بالمسؤولية عن احتجاز السفن بصورة غير مشروعة. r- قضايا منازعات العقود التجارية البحرية: ومن أهمها: قضايا المنازعات حول عقود النقل

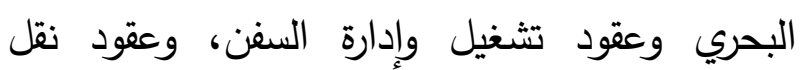
الركاب والأمتعة، وعقود التأمين البحري. r- قضايا المنازعات المتعلقة بتطوير واستخدام المياه البحرية وحماية البيئة:

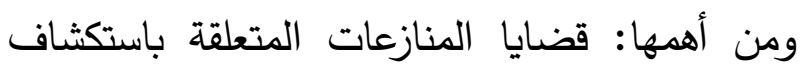

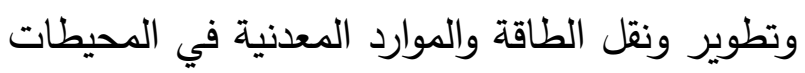
والبحار ، والقضايا المتعلقة بتطوير المناطق الساحلية

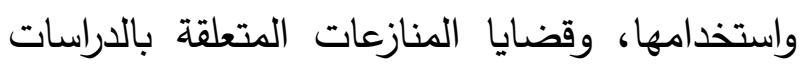

9. اعتمد هذا القانون في الاجتماع الثالث عشر للجنة الدائمة للمجلس

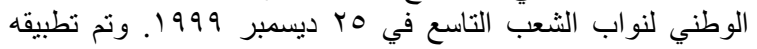

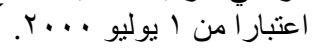

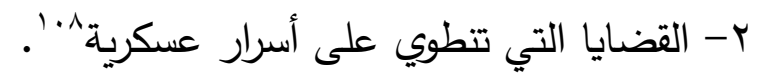

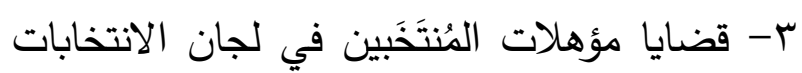
التي يُنْبُشُها الجيش. موهلات ع- قضايا تحديد الثروات غير المثلوكة داخل المناطق العسكرية.

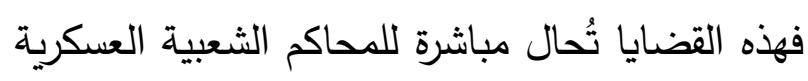

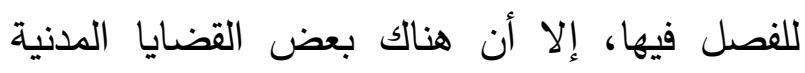

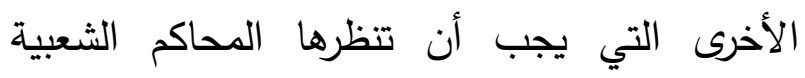

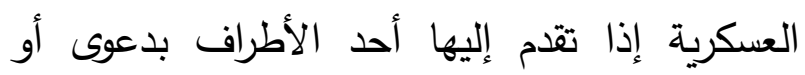
طلب، ومنها: 1- قضايا المنازعات المتعلقة المسؤولية عن الضرر

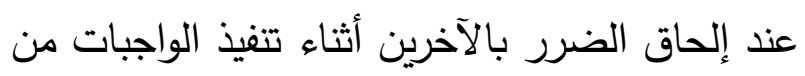
قبل العسكريين أو الوحدات العسكرية.

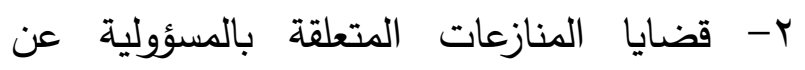

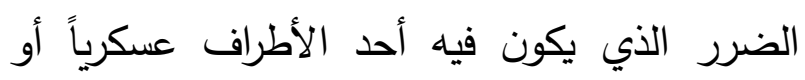

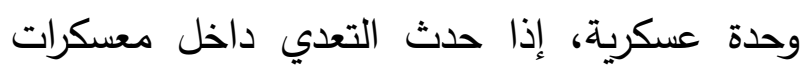

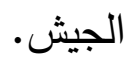
r- قضايا الأحوال الشخصية التي يكون فيها أحد الأطراف عسكرياً. ع- طلب إعلان حالة اختفاء أو وفاة عسكري.

\section{(ب) المحاكم البحرية} وهي إحدى أنواع المحاكم الثعبية الخاصة وتهنياه

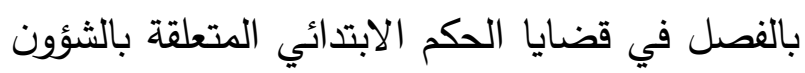

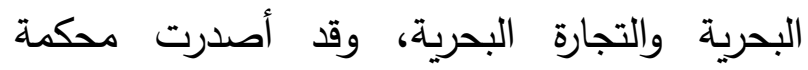

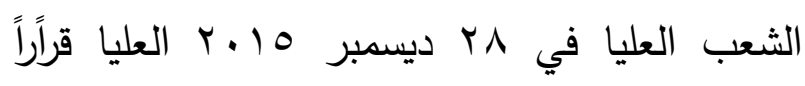

^• يشمل هذا النوع من القضايا كل ما كان على المستوى السري فأعلى 
تتفيذ أو إلغاء قرارات التحكيم الوطني البحري'"'

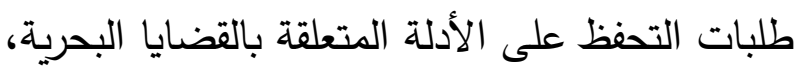
طلبات التحفظ على السفن أو شحنات محمولة على متن السفن أو مواد بحرية أو وقود بحري أو طلبات حفظ ممتلكات أخرى متعلقة بقضايا المنازعات

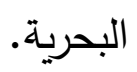

(ج) محاكم الملكية الفكرية

أنشأت جمهورية الصين الشعبية بقرار من المحكمة

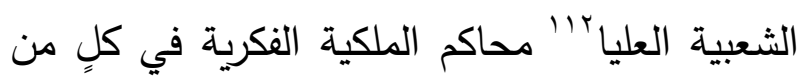
بكين وشانغهاي وقوانغجو "r"'، وذلك من أجل تعزيز وحماية حقوق الملكية الفكرية، وتحسين آلية الحوافز للابتكارات، ومن أبرز اختصاصات محاكم الملكية الفكرية القضايا الابتدائية التالية في نطاق التينات المدن الخاضعة لولاية محكمة الملكية الفكرية، وهي: 1- القضايا المدنية والإدارية المتعلقة ببراءات الاختراع، وأنواع النباتات الجديدة، وتصاميم الدوائر المتكاملة والأسرار الفنية والبرمجيات. r- دعاوى الاعتراض على الإجراءات الإدارية

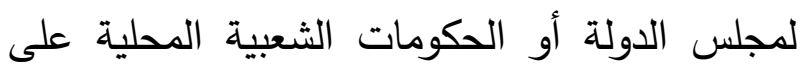
مستوى المحافظة أو أعلى منها، وذلك فيما يتعلق

'بخ يخع تنفيذ و إلغاء هذه القرارات لقانون جمهورية الصين الشعبية للتحكيم.

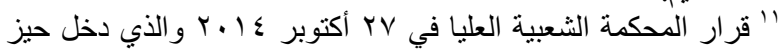

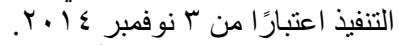

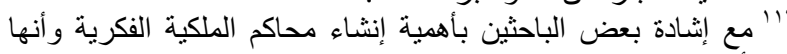

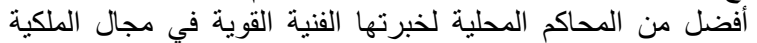

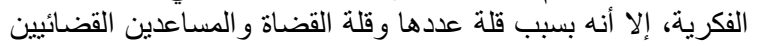

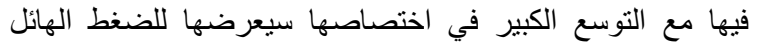

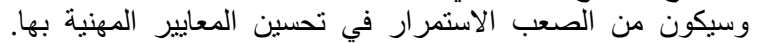

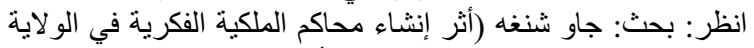

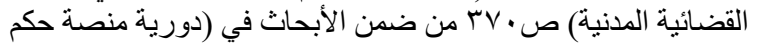

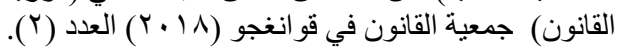

العلية البحرية، والقضايا المتعلقة بتلوث وتدمير البئُة البئة. ع- قضايا المنازعات البحرية وقضايا منازعات

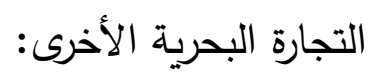
ومن أهمها: قضايا منازعات ملكية السفن وامتيازاتها،

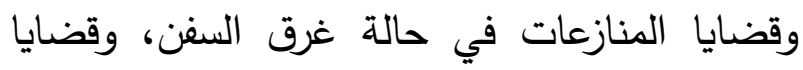

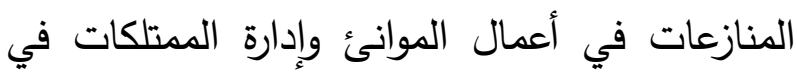

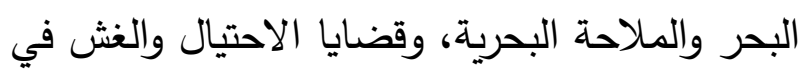

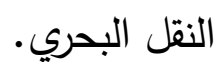
0- القضايا الإدارية البحرية:

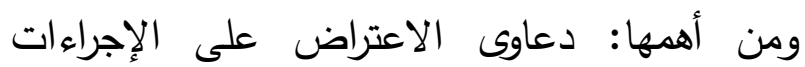
الإدارية التي يتخذها الجهاز الإداري البحري فيما

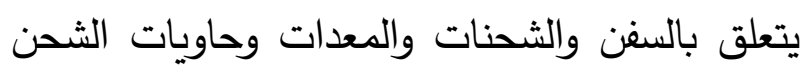

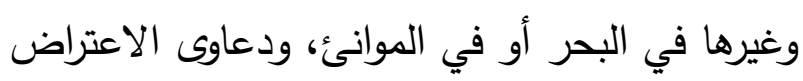

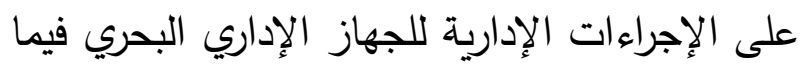

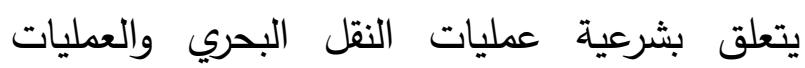
الإضافية ذات الصلة وعمليات الثحن وإيواء الطاقم وخدمات الصعود إلى السفن وما إلى ذلك. 7- الإجراءات الخاصة بالثؤون البحرية: ومن أهمها: طلبات تأكيد سريان الأثر القانوني الثاهي لاتفاق التحكيم البحري، وطلبات الاعتراف والتتفيذ

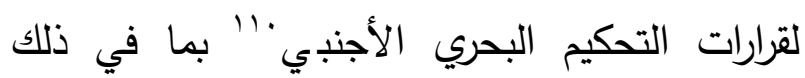

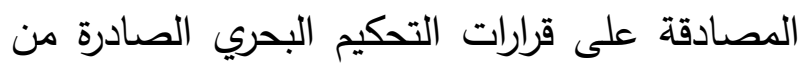

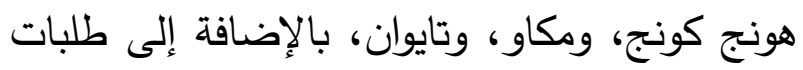

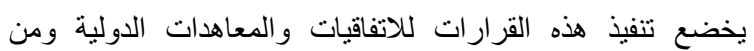

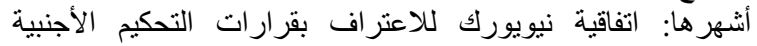

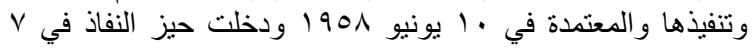

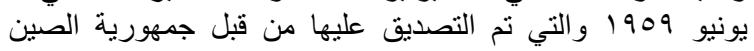

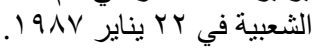


ا- قضايا المنازعات المتعلقة بالأوراق المالية والعقود الآجلة والائتمان والتأمين والفواتير وخطابات الاعتماد وعقود القروض والبطاقات المصرفية وعقود والاند والهن التأجير التمويلي وعقود التوكيل المالي والرهن.

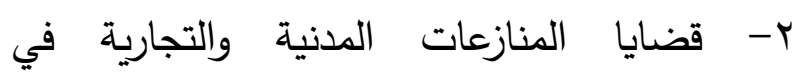
المعاملات المالية الجديدة مثل: منازعات خطاب وليات

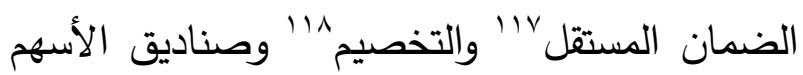

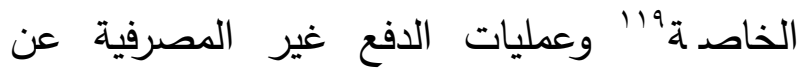
طريق الإنترنت r' والإقراض عن طريق الإنترنت

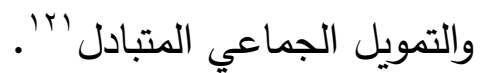

r- منازعات الإفلاس التي يكون فيها (المدين) مؤسسة مالية.

ع- التدقيق القضائي لقرارات التحكيم في المنازعات المدنية والتجارية المالية. 0- استلام طلبات الاعتراف والتنفيذ لأحكام المحاكم الأجنبية وقرارات التحكيم المتعلقة بالمنازعات المدنية والتجارية المالية.

"' خطاب الضمان المستقل: هو تعهذ يصدر من المصرف الضامن بناء

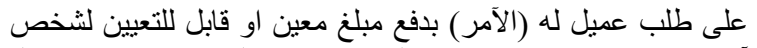

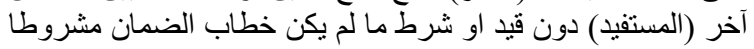

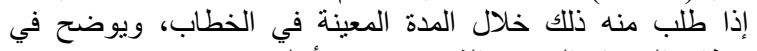

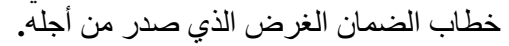

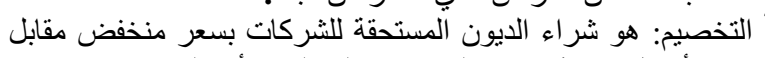
تقديم أمو ال فورية تساعد الثركات على الثى القيام بأعمالها.

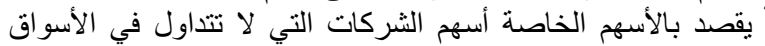

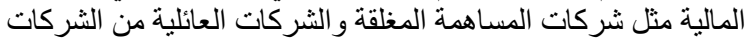

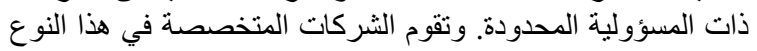

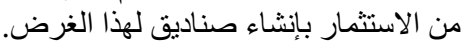

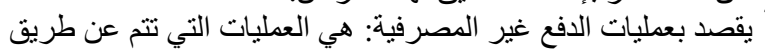

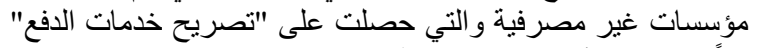

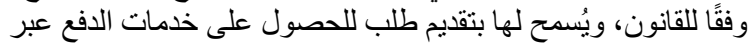

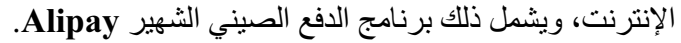

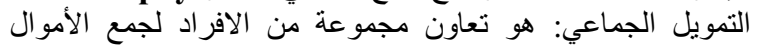

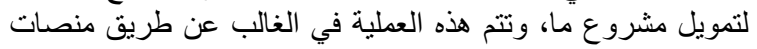
على شبكة الانترنت.
بحقوق النشر والعلامات التجارية والمنافسة غير

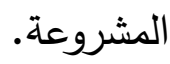
r- القضايا المدنية المتعلقة بالاعتراف بالعلامات التجارية المشهورة. وتكون محكمة قوانغجو للملكية الفكرية مختصة بالقضايا المحددة في الفقرتين (1) و (r) أعلاه في مقاطعة قوانغ دونغ كاملةً '" . وتقدم طلبات الاعتراض والاستئناف للأحكام الصادرة دوام من محاكم الملكية الفكرية السابقة إلى المحكمة الثعبية العالية بتلك المناطق التي تقع فيها محاكم الملكية الفكرية. (د) المحاكم المالية بقرار من المحكمة الشعبية العليا في بكين تم إنشاء

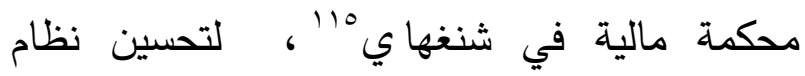
المحاكمات المالية وخلق بيئة مالية وقانونية جيدة"17" . وقد حددت المحكمة الشعبية العليا اختصاص المحكمة المالية وفقاً لقانون الدعاوى المدنية، وقانون الدعاوى الإدارية، ووفقاً لقرار اللجنة الدائمة للمجلس الوطني لنواب الشعب حول إنشاء محكمة شانغهاي المالية، وتختص محكمة شنغهاي المالية بالنظر في القضايا المالية والتجارية الابتدائية التي تقبلها محكمة الثعب المتوسطة في نطاق اختصاص مدينة شنغهاي وفق التالي:

"ا قوانغجو هي المدينة المركزية لدقاطعة قوانغ دونغ، وبالتالي نص

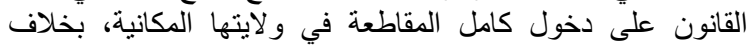
محكمتي بكين وشنغهاي فإنهما مدينتان خاضعتان فلان للحكومة المركزية مباثرة.

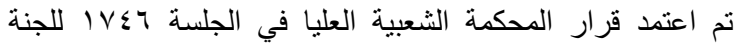

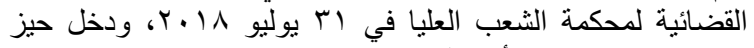

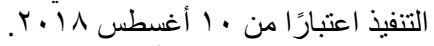

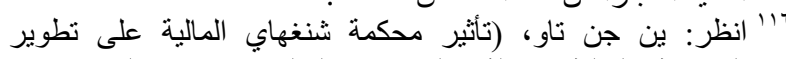

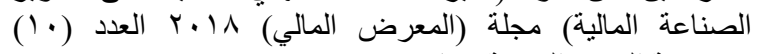
جمهورية الصين الثعبية - بكين. 
لتدخل الأجهزة الإدارية والمنظمات الاجتماعية والأفراد 'rr التخل r - بأ المساواة أمام القضاء : مباء يؤكد نظام المملكة العربية السعودية أن حقاء المقاء المقام المقام

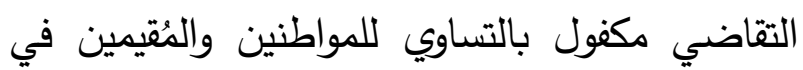

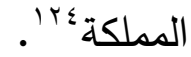

كما ينص قانون الصين أن يكون الجميع متساوون في القانون أمام القضاء، ولا يُسمح لأي لئي

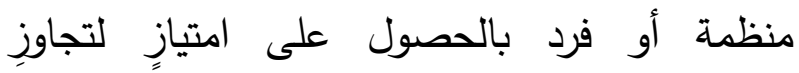

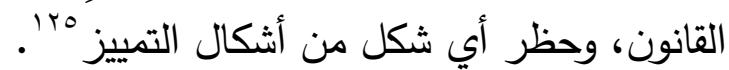
r- بأ تعدد درجات التقاضي:

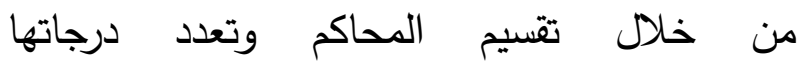
واختصاصاتها في كلا البلدين، يتضح لنا التزامهما التام بمبدأ تعدد درجات التقاضي، حيث يتهات يتاح لأطراف النزاع طلب مراجعة أحكامه وتدقيقها،

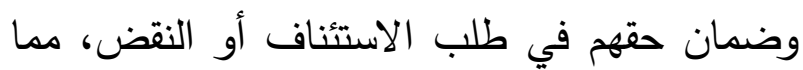
له تأثير كبير في شفافية القضاء وعدالته.

ثانياً: اختصاص المحكمة العليا: بعد مطالعة تتظيم المحاكم في قوانين البلدين نجد كلا البلدين تتفقان في إنشاء "المحكمة العليا" والتي

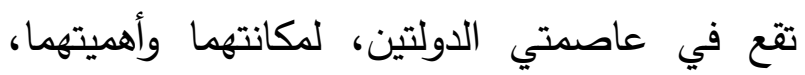
وتعتبر كلا المحكمتين أعلى سلطة قضائية، إلا أنه

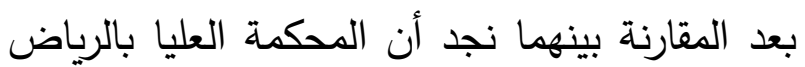
تتولى الأعمال القضائية ويتولى المجلس الألى الأعلى الإنى للقضاء الجوانب الإدارية من تعين القضاة والإشراف الإلئل

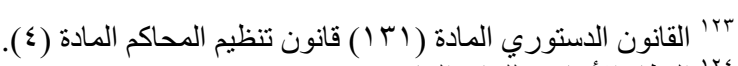

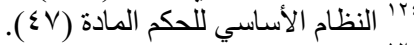

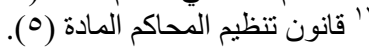

7- القضايا المالية والتجارية الابتدائية والقضايا الإدارية المالية التي تكون فيها المنشآت الأساسية للأسواق المالية في شنغهاي مدعى عليها. V- النظر في طلبات الاستئناف والنقض للأحكام والقرارات الابتدائية التجارية والمالية والقضايا الإدارية المالية التي تصدرها محكمة الشعب الابتدائية بشنغهاي. وتقدم طلبات الاعتراض والاستئناف للأحكام الصادرة من محكمة شنغهاي المالية إلى المحكمة الشعبية العالية بشنغهاي.

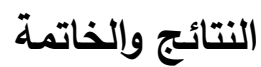
فهذه نبذة موجزة عن تشكيل المحاكم واختصاصاتها بكل من المملكة العربية السعودية وجمهورية الصين الشعبية، ومن خلال ذلك نود أن نجري مقارنة بين قانون كلٍ من الدولتين، وذلك من خلال النقاط التالية: أولاً: المبادئ القضائية: بالنظر إلى القوانين القضائية للبلدين نجدها تتفق في المبادئ التالية: - التئ 1 - مبدأ استقلالية القضاء: مبدأ استقلالية القضاء من أبرز مميزات القضاء

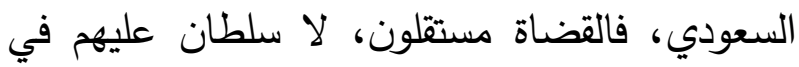
قضائهم لغير أحكام الثريعة الإسلامية والأنظمة المرعية، وليس لأحد التدخل في القضاء بَ' . وقد نصت كذلك قوانين جمهورية الصين الشعبية على هذا المبدأ، وأن المحاكم الشعبية تمارس سلطتها القضائية بشكل مستقل وفقاً للقانون، ولا تخضع

rr' النظام الأساسي للحكم المادة (7 ))، نظام القضاء المادة ( (1). 
المحكمة العامة وذلك في المدن الصغرى المئ والمحافظات الصغيرة.

وفي جمهورية الصين الشعبية نجدها قد أنشأت المحاكم البحرية المختصة بولية فالفصل في القضايا المتعلقة بالثؤون البحرية، كما أنشأت محاكم الملكية الفكرية، في كلٍ من بكين وشانغهاي وقوانغجو وذلك

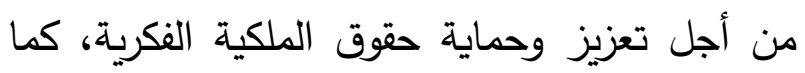
أنشأت المحكمة المالية في شنغهاي لتحسين وحئه نظام المحاكمات المالية. رابعاً- الاهتمام بالقضايا الكبرى: من خلال استعراض اختصاصات المحاكم في كلا البلدين نلحظ اهتماماً كبيرة بالقضايا التي تتعلق بالأمن الوطني، أو القضايا التي تتعلق بزعزعة أمن المجتمع أو وحدته، ولذا نجد المملكة العربية السعودية تشئ المحكمة الجزائية المتخصصة بالرياض لمباشرة هذا النوع من القضايا، بينما نجد قوانين جمهورية الصين الشعبية تتقل بعض القضايا لمحاكم الدرجة الثانية أو الثالثة لتعلقها بالأمن الوطني، بل يمكن في بعض القضايا أن تتولى المحكمة الشعبية العليا بذاتها الفصل في القضايا

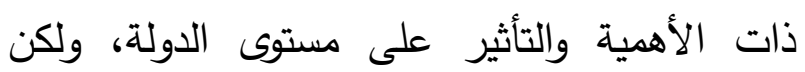
بظني أن قوانين جمهورية الصين الثعبية لم تحدد الاختصاص في هذه القضايا بأوصاف دقيقة يمكن

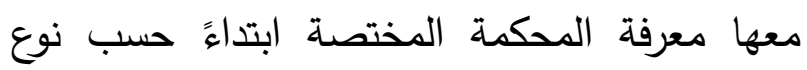
القضية، بل تخضع أولاً القضية للدراسة ثم تحال للمحكمة المناسبة، وأحياناً قد تبدأ في المحكمة الابتدائية ولكن لصعوبتها أو إبهامها يتم نقلها

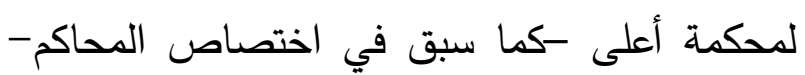

عليهم وعلى المحاكم الخ. بينما نجد المحكمة العليا بيكين تتولى كلا الجانبين فتتولى بنفسها الإشراف على المحاكم وفي ذات الوقت يوكل إليها نظر لتربي بعض القضايا واستئناف ونقض قضايا أخرى. وبظني أن نظام المملكة العربية السعودية قد وفق في هذا الجانب بفصل الجانب الإداري عن الجانب القضائي وفي ذات الوقت لـ يكن ذلك الفصل كلياً بل نجد رئيس المحكمة العليا هو أحد أعضاء المجلس الأعلى للقضاء والذي له الدور الكبير في الانسجام بين قرارات كلا الجهتين. بالإضافة إلى استقلال القضاء الإداري بدرجاته المختلفة عن المحكمة العليا بالرياض، حيث يتولى لئ لإهاء

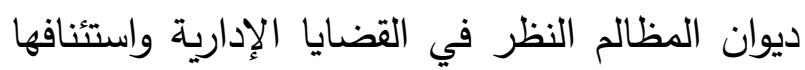
ونقضها. بينما تشرف "المحكمة الشعبية العليا" ببكين على جميع أنواع القضايا ومنها القضايا الإدارية. ثالثاً - التحول للقضاء المتخ المصص. مع تسارع التطور وتشعب مجالات الحياة وتعقيداتها، أصبحت الحاجة ملحة إلى التحول إلى القضاء المتخصص، لسرعة البت في القضايا، وتأهيل القضاة في مجالات اختصاصهم، وتطوير الأنظمة العدلية لمواكبة هذا التسارع، ولاسيما في مجال القضاء التجاري، مع تعدد القوانين، وكثرة النوازل وتشعبها وتداخلها أحياناً. ولذا فإن القضاء التهاء في كلا البلدين يتجه وبسرعة كبيرة للقضاء المتخصص، لاسيما في المدن الكبرى، ففي المملكة

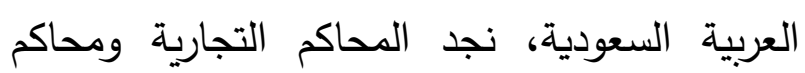
الأحوال الشخصية والمحاكم الإدارية والمحاكم العمالية ومحاكم التنفيذ في المدن الكبرى، وما عداها فيكون القضاء فيه على شكل دوائر متخصصة في 
- نظام التفيذ السعودي الصادر بالمرسوم الملكي

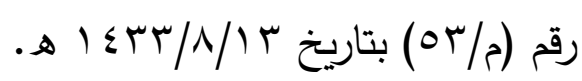
- نظام التحكيم السعودي الصادر بالمرسوم الملكي

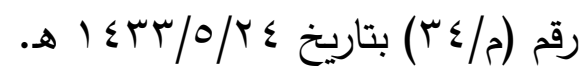

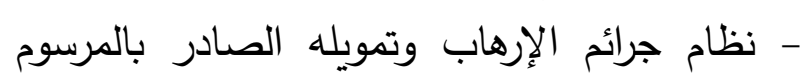

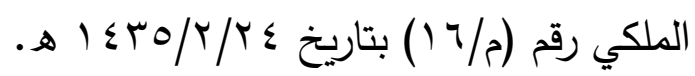
- القانون الدستوري لجمهورية الصين الشعبية:

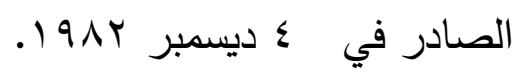
- قانون جمهورية الصين الشعبية لتظيم المحاكم:

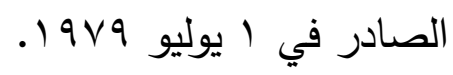
- قانون جمهورية الصين الشعبية للدعاوى المدنية:

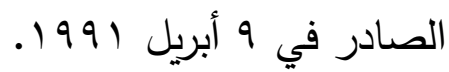
- قانون جمهورية الصين الشعبية للدعاوى الإدارية:

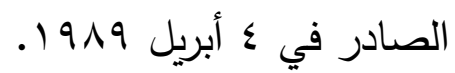
- قانون جمهورية الصين الثعبية للدعاوى الجنائية:

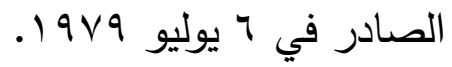
- قانون جمهورية الصين الشعبية للتحكيم: الصادر

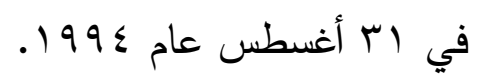
- قانون جمهورية الصين الشعبية لإجراءات الخاصة بالدعاوى البحرية: الصادر في هب ديسمبر .1999

- قرار المحكمة الشعبية العليا في ·r أغسطس

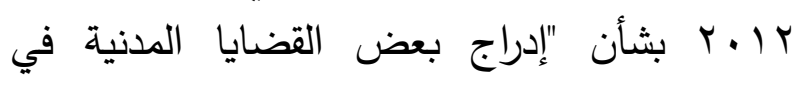
اختصاص المحاكم العسكرية".

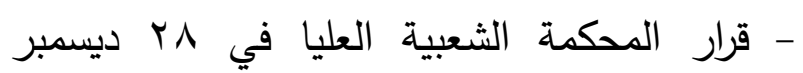

1 • ب العليا بشأن "اختصاص المحاكم البحرية". - قرار المحكمة الشعبية العليا في ب أكتوبر ع ا. r بشأن "إنشاء محاكم الملكية الفكرية وتحديد

اختصاصها".
وربما يعزى ذلك إلى قلة هذا النوع من القضايا، فتلزم دراسته أولاً لتحديد المحكمة المناسبة. وختاماً: فإن ما تشهده البلدان من تواصل مستحر بين وزارتي العدل، وتبادل الزيارات والاطلاع على فلى لخدان الخبرات والتجارب، يساعد كلا البلدين على الاستفادة من تجارب الدولة الأخرى، وصولاً للغاية العليا وهي إقامة العدل، وتذليل كل عقبة في سبيل ذلكا، واستخدام التقنيات الحديثة في هذا المجال، حيث تمتلك جمهورية الصين الشعبية خبرة كبيرة في هذا الشأن. ونحن بلاشك بحاجةٍ لمزيدٍ من الدراسات والمقالات العلمية حول قوانين جمهورية الصين الشعبية لاسيما ما يتعلق منها بالجانب التجاري. والله الموفق قائمة المصادر والمراجع القوانين والقرارات : - نظام القضاء السعودي الصادر بقرار مجلس

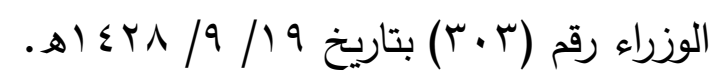

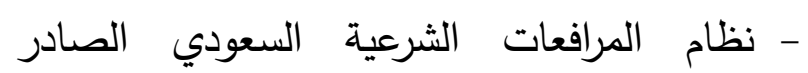

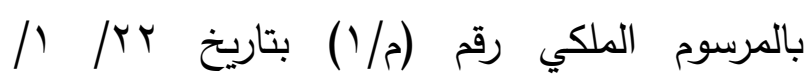
هـ - نظام ديوان المظالم السعودي الصادر بالمرسوم الملكي رقم (م//

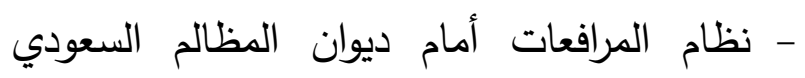
الصادر بالمرسوم الملكي رقم (م/r) بتاريخ أه - نظام الإجراءات الجزائية السعودي الصادر

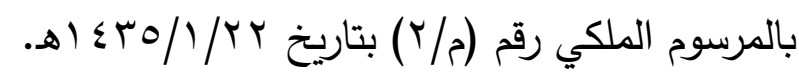
- نظام العمل السعودي الصادر بالمرسوم الملكي

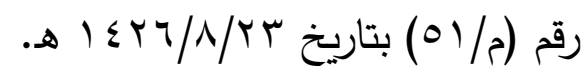




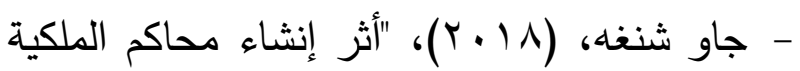

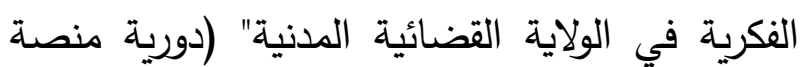
حكم القانون) العدد (r) جمهورية الصين الشعبية قوانغجو.

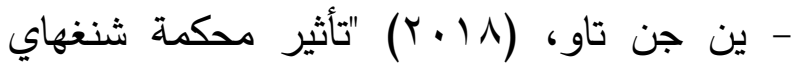

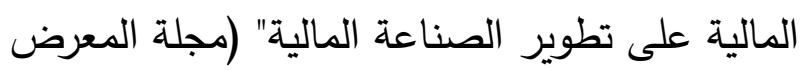
المالي) العدد (·) (1) جمهورية الصين الثعبية بكين
- قرار المحكمة الشعبية العليا في ابم يوليو 1 ا ـ Y، بشأن "إنشاء محكمة شنغهاي المالية وتحديد

اختصاصها". الدوريات: - - الدات

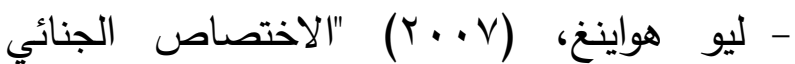
للمحاكم العسكرية" مجلة معهد شيان للعلوم السياسية، المجلد (·r) العدد (؟) جمهورية الصين الشعبية: شيان.

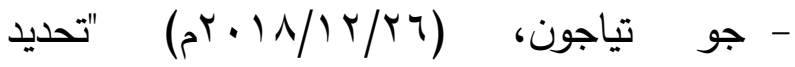
الاختصاص في القضايا الجنائية" صحيفة المحكمة الشعبية. 


\title{
Organization and purviews of courts in the People's Republic of China Comparative Study of the Courts of the Kingdom Saudi Arabia
}

\author{
Mohammed Ayedh Aseri \\ King Abdulaziz University \\ Faculty of Arts \& Humanities \\ Department of General Courses
}

\begin{abstract}
In light of the development and economic growth witnessed by the People's Republic of China, which ranks second in the world economy, and attracts thousands of traders and investors from all around the world to import, export, and invest, and millions of transactions and contracts are concluded during these commercial operations, and some parties resort to the courts of the People's Republic of China to separate in disputes. The multiplicity of courts and their different degrees and jurisdictions in the People's Republic of China, the importance of knowledge utilization from the legal experiences of other countries, the importance of conducting comparative studies, especially those with which we have close economic and commercial relations. This article explains the types, levels, and jurisdictions of courts in Saudi Arabia through an inductive study of the judicial systems in the Kingdom of Saudi Arabia, and compares them to the types of courts and their jurisdictions in the People's Republic of China. It then outlines points of agreements and differences between them, and what can be learned of that in the development of the judiciary.

Courts in the Kingdom of Saudi Arabia are divided into two parts: the courts that fall under the Supreme Council of the Judiciary: the Supreme Court, the Courts of Appeal, the First Courts. These include General Courts - Criminal Courts - civil Status Courts - Commercial Courts - Labor Courts - Execution Courts.

Section II: Administrative courts under the Board of office of the ombudsman: Supreme Court, Appeals Courts, and Administrative Courts.

Courts of the People's Republic of China are divided into the Supreme People's Court, the local People's Courts, and the People's Special Courts. The Supreme People's Court is the highest judicial system in the state, and it decides on important cases at the state level, as well as supervising the rest of the courts. The local people's courts are divided into: the People's Court of First Instance, the Intermediate People's Court, the High People's Court, and the Special People's Courts, including military courts, maritime courts, intellectual property courts, financial courts, and others.
\end{abstract}

